\title{
LA SUFIXACIÓ EN LA PREMSA VALENCIANA DEL SEGLE XIX
}

\author{
JOAQUIM MARTÍ MESTRE \\ Universitat de València \\ joaquin.marti@uv.es
}

\section{RESUM}

El Mole, una de les primeres i més rellevants manifestacions periodístiques en llengua catalana, va partir d'un model lingüístic popular i modern, basat en la literatura popularista contemporània, que els redactors van procurar combinar amb un registre més formal segons el tipus d'article. L'actualitat del periòdic els duu a reflectir el llenguatge de l'època, però també a practicar la formació de noves paraules a través dels recursos interns de l'idioma, com la derivació. En aquest article estudiem els sufixos que apareixen en El Mole, i veiem com expressen en part la realitat lingüística del català del segle XIX en la seua varietat valenciana, i en part la creativitat dels seus redactors. Igualment, s'estudien les veus de major interès formades mitjançant aquest procediment. Comparem, quan cal, les formes d'El Mole amb les dels textos contemporanis.

Mots CLAU: Premsa, Segle XIX, País Valencià, Llenguatge periodístic, Formació de paraules, sufixació.

\section{THE SUFFIXATION IN THE VALENCIAN PRESS OF THE 19'1 CENTURY}

\section{ABSTRACT}

El Mole, one of the first newspapers in Catalan language, used a popular and modern language based on contemporary popular literature that the authors blended with a more formal register according to each one of the articles. The editors made use of a contemporary language linked with the reality they were living and at the same time developed a creative use of the language by using word formation mechanisms, like suffixation. In this paper we study the suffixes of $E l$ Mole, and we see how they express the 19th century Catalan linguistic reality in its Valencian variety and the linguistic creativity of the editors. Furthermore, we focus on the words of major interest formed by suffixation. We compare also the linguistic forms of this newspaper with other contemporary Catalan texts.

KEYWORDS: Press, 19th century, Valencian country, Journalistic language, Word formation, Suffixation.

\section{EL MODEL LINGÜÍSTIC D’EL MOLE I LA SUFIXACIÓ.}

El Mole és una de les primeres publicacions periòdiques en llengua catalana ${ }^{1} \mathrm{i}$ una de les més rellevants. Malgrat les imposicions de la nova llei d'impremta i les limitacions econòmiques que l'afectaren, assolí una gran difusió i popularitat, entre quatre mil i cinc mil lectors durant la segona època, als quals caldria sumar

\footnotetext{
${ }^{1}$ Sobre la premsa en llengua catalana al segle XIX, veg. Guillamet (2015).
} 
el públic, en gran part analfabet, que hi accedia com a oient a través de lectures col-lectives. ${ }^{2}$ El redactor principal del periòdic era Josep Maria Bonilla, que va comptar amb la col-laboració de Josep Bernat i Baldoví i de Pasqual Pérez. Encara que de forma discontínua, es va publicar entre 1837 i 1870, durant cinc èpoques diferents. La primera, l'any 1837, de l'1 de febrer al 31 d'agost; la segona, entre el 3 de novembre de 1840 i el 9 de juliol de 1841; la tercera, del 16 de gener de 1855 al 23 de febrer de 1856. Entre 1863 i 1864 es va publicar com a suplement a $E l$ Porvenir, del 2 de novembre de 1863 al 23 de maig de 1864; i, sense que s'indique expressament en el periòdic que conforme una altra època, del 22 d'agost de 1864 al 20 de març de 1865 es publica amb el títol d'El Mole Antic com a "suplement als Dos Reines". ${ }^{4}$ La cinquena i darrera època comprén quinze números, entre el 24 de febrer i el 6 de juny de 1870. En la quarta època, tant en l'etapa de suplement a El Porvenir com en la de Los Dos Reinos, Josep Maria Bonilla sembla que ja era el redactor únic, segons es desprén de la informació de la darrera pàgina de cada número: "Por todo el número: José María Bonilla".

Els redactors d'El Mole s'enfrontaren amb el problema d'haver d'elaborar un discurs periodístic en català, i això, juntament amb la situació de minorització que patia la llengua pròpia, sense a penes referents contemporanis cultes als quals poder acudir, va fer que es preocupessen des del primer moment pel model lingüístic que havien de fer servir en la publicació. En aquest sentit tingueren en compte tant el públic al qual s'adreçaven com les exigències del gènere periodístic. El Mole, com la premsa satírica del segle XIX en general, anava destinat principalment als sectors populars, acostumats a llegir o escoltar textos en català en un registre col-loquial, com el que trobaven en els col-loquis satírics i burlescos. Els redactors d'El Mole partiren, doncs, d'aquest model, que els permetia connectar millor amb el seu públic potencial, però, conscients de l'aptitud del valencià per als assumptes cultes i per als registres formals, i no únicament per als populars i informals (Simbor 1989: 14), ${ }^{5}$ i pensant segurament que les exigències de la premsa devien ser diferents a les de la literatura popular, i que, segons el tema o el tractament de la notícia o del comentari, s'hi podia fer servir un registre més formal, distingeixen expressament dos tipus d'estil: un "estil

\footnotetext{
2 Veg. Balaguer (1988: 70).

${ }^{3}$ Així com les èpoques tercera i quarta (fins el 23 de maig de 1864) són indicades expressament en la capçalera de la publicació, el període d'El Mole Antic no porta cap indicació sobre l'època. De manera que podríem considerar aquest període com una segona etapa de la quarta època. En la darrera aparició del periòdic, en 1870, s'assenyala en la capçalera que és la " 5 a època".

${ }^{4}$ Es tracta del periòdic Los Dos Reinos, fundat a València el 16 d'agost de 1864 per Josep Peris i Valero, cap del partit progressista.

${ }^{5}$ Manuel Civera (1820), autor de les conversasions entre Saro Perrengue i el Dotor Cudol, ja lamentava el menyspreu i degradació del valencià, i es referia a la seua aptitud per a tractar sobre qualsevol tema, al mateix nivell que les altres llengües. Alguns investigadors consideren aquestes conversasions, que conegueren tres èpoques, des de l'any 1809, com "el primer periòdic en valencià" (Martínez-Gallego 2015: 190); altres, però, veuen els plecs de cordell més aviat com a precedents del periodisme pròpiament dit (veg. Codonyer 2000: 15).
} 
cult" i un "estil ordinari y vulgar" (1837: I, 26), i es proposen de fer servir tots dos registres en el periòdic, segons el tipus d'article.

D'altra banda, com cabia esperar d'una publicació d'actualitat destinada a un públic popular, els redactors d'El Mole adopten en la publicació un "estil modern", ${ }^{6}$ i afirmen que els idiomes, en cas de necessitar nous vocables, tenen l'opció d'acudir a les llengües clàssiques (llatí i grec), de manllevar vocables d'altres llengües modernes, i afegeixen que "sempre que per a espresar conseptes moderns, cregam indispensable recurrir a la creasió de noves paraules, ho farem, però usant del mirament y parsimònia que en tals casos aconsella Horasi" (1837: I, 26-27). En efecte, en la formació de noves paraules recorren tant als cultismes i als manlleus d'altres llengües modernes com a la creació lèxica usant els recursos interns de l'idioma, entre els quals destaquen la derivació i la composició.

Aquestes paraules dels redactors d'El Mole proven la importància que per a ells tenia la derivació en la formació de mots. Dins de la derivació, ocupa un lloc destacat per la seua productivitat en el periòdic la sufixació. L'objectiu d'aquest treball és l'estudi de la sufixació en El Mole, especialment inventariar i comentar els sufixos d'interés enregistrats, ordenats alfabèticament per tal de facilitar-ne la consulta. ${ }^{7}$ L'interés dels sufixos recollits es troba, segons el cas, en el seu origen, en la variació formal que presenten, en els seus matisos expressius, o en el tractament que tenen en valencià. Igualment, en alguns casos donen origen a mots, accepcions o variants no enregistrades o no documentades en els diccionaris històrics, descriptius ni normatius, així com a veus de caràcter dialectal. Alguns dels sufixos descrits semblen patir actualment, almenys en valencià, una certa reculada (-alla,-am,-im). Algunes veus formades per sufixació són documentades només en El Mole, o documentades ací per primera vegada. $S$ 'analitza el valor que tenen els diferents sufixos, així com les variants formals que en alguns casos adopten. Igualment, amb la intenció de contribuir a millorar el coneixement del lèxic valencià del segle XIX, s'estudien les veus de més interés formades per sufixació. Quan cal, es comparen les formes d'El Mole amb les dels textos contemporanis. Situem el signe $\left(^{*}\right)$ davant dels mots no registrats en el DCVB, en el DECat ni en el DAg, $\left(^{* *}\right)$ davant les accepcions no registrades, $\left(^{\circ}\right)$ davant els mots o accepcions no documentades, $\mathrm{i}(+)$ davant els mots que avancen la primera documentació respecte a aquests diccionaris.

${ }^{6}$ El Mole participa així d'una tendència a la modernització de la llengua literària que es troba ja en autors valencians dels segles XVII, com Gaspar Escolano i Marc Antoni Ortí, i XVIII, com Carles Ros i Marc Antoni d'Orellana. Una postura renovadora en matèria lingüística, pel que fa al castellà, es troba també en Larra i en gramàtics contemporanis com Bello (veg. Lapesa 1984: 7981).

${ }^{7}$ Com diu Martines (2000: 284-285), per tal de caracteritzar els mecanismes de creativitat lèxica d'una determinada època, "és fonamental disposar d'un inventari de morfemes tan complet com siga possible i d'una descripció del joc que permet cadascun". 


\section{SUFIXOS}

\subsection{Els sufixos -ada i -ador, -adora}

En el sufix -ada (llatí -ATA) es troba tant la conservació de la $d$ com la forma reduïda -à. A la primera meitat del segle XIX assistim a una etapa de transició entre la conservació de la $d$ intervocàlica en - $a d a$ i la seua pèrdua, que acabarà imposant-se en valencià al darrer quart del segle XIX. En aquesta etapa juntament amb els casos d'elisió de la consonant dental, també n'hi ha alguns de manteniment de les dues vocals àa, tant en El Mole: m'agràa (1837: I, 221; II, 271), espràa (1837: I, 351), ${ }^{8}$ com en altres textos valencians: "sa corbata enrandàa",, "eixa desculàa, llecha, / Senta la de Campanar". ${ }^{10}$

Trobem el sufix -ada (-à) en El Mole en la formació de substantius a partir de noms indicant 'acció pròpia de', amb un valor pejoratiu: 'baconada 'acció indigna, indecent' (1837: I, 101), ${ }^{11}{ }^{*}$ calomardà (1837: I, 151, 152), derivat del cognom del polític espanyol Calomarde, *romanticada (1837: II, 135), ${ }^{12}$ amb valor col·lectiu o intensiu: +novellaes 'conjunts d'infants' (1837: II, 222), ${ }^{13}$ panaes (1840-41: I, 67), paraulaes (1837: I, 15), indicador de colp: +baquinada (1837: I, 87), ${ }^{14}$ bofetaes (1837: I, 138), ${ }^{* *}$ cuiraes 'colps pegats amb un cuir' (1855: I, 318), 'culataes (1837: I, 138), garrotà (1863: 83), pernaes (1837: II, 126), +samugà (1837: I, 135),15 +tamborinà (1837: I, 135), tamborinades (1837: I, 14, 148), tamborinaes (1837: I, 16), +trabucà (1837: I, 135); en ${ }^{* *}$ molà (1855: I, 15; 1855: II, 34) és referit a cadascun dels números d'El

8 També en Maalenes ("el convent de Maalenes") (1837: I, 192), amb simplificació del grup consonàntic intervocàlic $-g d->-d$ - i posterior elisió de la dental aproximant intervocàlica en la seqüència -ada-.

${ }^{9}$ Colecsió de vàries conversasions alusives al nou sistema consitucional que pasaren entre els dos acreditats patriotes Saro Perrengue y el dotor Cudol, València, 1820, p. 69.

${ }^{10}$ Les marors de una fadrina o El viudo vert, València, 1860, p. 38.

${ }^{11}$ En el DCVB baconada 'cosa molt bruta o acció indecent' figura com a valencià, sense documentació. En el DGLC 'acció, paraula, bruta', en el DIEC 'acció o paraula molt bruta, indecent', en el DNV 'acció o paraula bruta', en el DDLC 'brutícia' documentada en Puig i Ferreter (1934), i 'porqueria' en Joan Oliver i Feliu Formosa (1963). Encara que el DCVB registra aquest mot només en valencià, veiem que també és usat per autors del Principat, i Labèrnia (1839) inclou baconada 'porqueria', 'atsegallada' com a veu "peculiar de una de las quatre províncias".

${ }^{12}$ Cfr. "-Muger! / Cese tu decir fatal: / que encierra cada palabra / veneno que daño labra / imposible del puñal. / -(Ya ix en les romanticaes)" (Joan Colom, Lo que fa la roba, Castelló, 1875, p. 35). Romanticada i calomardada es documenten també en castellà, encara que no figuren en el DRAE.

${ }^{13}$ Els diccionaris normatius, com també el DECat $(\mathrm{V}, 974)$, registren novellada referit només als animals petits, novells. En el DCVB s'aplica també, figuradament, al 'conjunt d'infants nascuts de poc'.

${ }^{14}$ Mot valencià, segons el DCVB i el DAg. No es registra en el DECat, com tampoc en el DGLC, en el DIEC ni en el DDLC, però sí en el DNV.

${ }^{15}$ Mot valencià (DCVB; DECat, VII, 649, 651-652). Es documenta ja al segle XVIII: “Per lleu, y que samugada / que mereixia en lo cap!" (c. 1735) (Raonament que tingueren dos llauradors de el poble de Vinalesa, BUV, ms. 668, p. 7). No es registra en el DGLC ni en el DIEC, però sí en el DNV i en el DDLC. 
Mole. ${ }^{16}$ Com a sufix nominalitzador de verbs, que forma substantius indicadors d'acció i efecte: ${ }^{* *}$ afluixada 'pagament' (1837: I, 314), ${ }^{17}{ }^{\circ}$ bramaes (1837: II, 248), 'donaetes 'donacions' (1837: II, 144), ${ }^{18}+$ empastrada (1837: I, 13), ${ }^{19}$ 'enclavada (1837: II, 326), *esmerada 'desgast per l'ús continu' (1837: II, 164), **estufarrada 'esquitx, porció d'aigua llançada amb un estufador' (1837: II, 249), menchada (1837: I, 96).

El substantiu carchotada (1837: I, 334; II, 293), plural carchotaes (1837: II, 310), figura en el DCVB amb el sentit de 'carxot', documentat en Joaquim Amo. En el DNV es registra amb el sentit de 'carxot fort', segurament pensant en un derivat intensiu de carxot 'colp fort al bescoll pegat amb la mà oberta' ${ }^{20}$ Carxotada s'aplica en els textos citats d'El Mole als colps pegats en la processó del Corpus amb el carxot de la Degolla, ${ }^{21}$ i en sentit figurat a un atac o agressió o a una derrota militar (1837: I, 334; II, 293, 310), juntament amb el verb carxotar, ací 'atacar i derrotar (un enemic, en una guerra)'.22

Igualment, en el sufix -ador, -adora (llatí -ATORE) conviuen en El Mole els casos de manteniment i d'elisió de la consonant dental. Aquest sufix forma substantius i adjectius que indiquen l'agent (cfr. Moll, 2006: 260): ${ }^{\circ}$ aponderaors (1837: I, 91), arreplegador (1837: I, 112), ’destrosaor (1837: I, 189), *engabiaor (184041: II, 145), parlador (1837: I, 90), regaora (1837: I, 152, 195), i la que deu ser una creació dels redactors d'El Mole, *desgobernaor: “al poble español no li ha·mostrat res el gobern, o el desgobern, per millor dir, y después que entre els desgobernaors y els crancs l'han consumit en la ignorànsia" (1840-41: I, 24), "El gobern español desgobernaor" (1840-41: I 253), construcció antitètica, en relació amb els mals governants, neologisme format a partir de desgovern, per referència a un mal govern, en contrast amb els governadors.

El sufix -adora el veiem també aplicat a objectes o instruments usats amb la funció que expressa el lexema: *estrañinadora (1837: II, 307) i *estrañinaora (1840-

\footnotetext{
${ }^{16}$ Creació dels redactors d'El Mole, probablement jugant amb l'homonímia amb molada 'colp pegat amb una mola', tenint en compte el caràcter crític i satíric del periòdic.

${ }^{17}$ Derivat d'afluixar 'pagar'.

${ }^{18}$ En el DCVB donada 'acte de donar; especialment, acte de repartir les cartes als jugadors', però en el cas que ens ocupa és sinònim de donació, acció de donar.

${ }^{19}$ Mot propi del valencià (DCVB; DECat, III, 303). El recullen el DNV i el DDLC, però no el DGLC ni el DIEC.

${ }^{20}$ No es registra en el DGLC, en el DIEC ni en el DDLC.

${ }^{21}$ La referència al carxot de la Degolla es documenta en el mateix periòdic El Mole, on es critica aquesta tradició festiva (1837: II, 123-124). En el DCVB es registra el carxot de la Degolla en valencià, però sense documentació.

22 Igualment en: "Anaben a carchotar als facsiosos en Navarra" (1837: I, 316), aplicat, així mateix, als carlins. Carxotada formalment podria entendre's com un derivat de carxot amb el sentit de 'corretja de tela o de pergamí que porten les persones que, en la Degolla, representen els soldats del rei Herodes, $i$ amb la qual peguen als espectadors', amb el sufix -ada designador de colp donat amb un objecte; així, en EscLl s'inclou carjotada només amb el sentit de 'golpe dado con el carjot'; també podria analitzar-se carxotada com un derivat del verb carxotar 'pegar carxots (a algú)' (DNV), derivat de carxot, sobretot si entenem carxotada com un sinònim de carxot, com fan el DCVB i MGad. El verb carjotar 'cascar' figura en Sanelo (DECat, II, 602).
} 
41: I, 346), talladora (1837: I, 195). La primera i la segona formes són variants d'esteranyinadora, derivat de teranyina, com el verb esteranyinar, amb el prefix esindicador de supressió (DCVB). Conté una síncope de la $e$ interior pretònica en contacte $\mathrm{amb}$ la ròtica. Altres variants d'aquest mot que documentem en valencià són: esterenyinadora (esterenyinaora), ${ }^{23}$ amb canvi de la $a$ en $e$ probablement per assimilació al timbre de les vocals de les dues primeres síllabes, així com al caràcter palatal de la consonant nasal en contacte, estrenyinadora, ${ }^{24}$ en aquest cas amb síncope de la primera vocal interior pretònica; esterinyadora (Llorente Falcó 2001: III, 382), amb palatalització de la segona vocal interior pretònica en contacte amb la consonant nasal palatal o reducció i substitució per la $i$ de la síllaba següent, i eliminació per dissimilació d'una de les dues consonants nasals, i estranyidaora (1855: I, 367), que sembla producte d'una metàtesi de la consonant dental i eliminació de la segona nasal, juntament, en el mateix text, amb el derivat estranyidaorà, que assenyala el colp pegat amb aquest objecte, amb la variant estranyiorà, que suposa una elisió de la - $d$ - intervocàlica, i una simplificació del grup vocàlic resultant $a o>0 .{ }^{25}$

\subsection{Els sufixos $-a l,-a r$}

El sufix llatí -ALIS, -E / -ARIS, -E, originàriament indicador de pertinença, presentava l'una o l'altra variant d'acord amb condicionaments fonètics; de manera que la forma bàsica -ALIS es canviava en -ARIS, per dissimilació, si el substantiu primitiu contenia una consonant lateral. Aquesta alternança morfofonològica llatina es retroba en les llengües romàniques que han conservat els descendents d'aquest sufix, encara que s'hi troben diferències quant al predomini de l'una o l'altra variant, amb una major o menor fidelitat a la norma fonètica llatina. Cal dir que en català s'ha expandit, per relació a la norma llatina, la variant -ar, més en el català oriental (central i balear) que en l'occidental (cfr. Colomina 2017).

Amb caràcter col-lectiu, per designar camps de plantes cultivades i llocs on abunden plantes o arbusts silvestres, en El Mole es fa servir el sufix -ar en ${ }^{\circ}$ arrosar (1863: 42), ${ }^{\circ}$ bachocar (1840-41: I, 92), ${ }^{26}{ }^{*}$ brosar $^{27}$ i cañar (1840-41: I, 290). En mots amb

${ }^{23}$ "S' asoma al balconet en una estereñinaora envolicà en una toballa, y en ella pega arreu" (Faust Hernández Casajuna: El pati dels cañarets, Madrid, 1914, p. 25), documentada ja al segle XVII, en la "vuit jochs de debanadores, / tres dits de drap de pintures, / [...] y hu de estereñinadores" (Morell 1986: 127).

24 "provaren a rematar-los a granerades blandint estrenyinadores" (Josep Pascual Tirado: De la meua garbera, Castelló, 1935, p. 26).

${ }^{25}$ Els diccionaris històrics no registren aquestes formes, amb l'única excepció d'estrenyinadora, que recull el DCVB, però sense documentació.

${ }^{26}$ Mot valencià i tortosí, segons el DCVB. Es documenta ja a principis del XIX: “Que ha collit lo bajocar?" (Proclama en forma de coloqui, València, 1808, p. 1).

${ }^{27}$ Aquest en un topònim de l'Albufera (1863: 43). Encara que els diccionaris normatius i històrics no registren el substantiu brossar per referència a un lloc on abunda la brossa, sí que és conegut 
sentit figurat, per referència a una situació confusa, dificultosa, complexa, crítica, apareix el sufix -ar en ${ }^{\circ}$ fangar (1837: II, 53), **fabar (1837: II, 133) i *merengenar, merenjenar (1837: I, 246; 1840-41: I, 203; 1864: 283), adaptació del castellà berenjenal 'embrollo, jaleo, lío' (veg. Martí 2006), amb canvi del sufix -al en -ar. El canvi, que podria estar afavorit per assimilació a l'altra bategant del mot, deu ser analògic a les veus d'un sentit similar que contenen aquest sufix, com és el cas de fangar i favar, i del valencià alberginar 'camp plantat d'albergines' (DCVB).

Amb el sentit també de situació difícil, complicada, es fa servir el sufix -al en tarquimal: "No eixirem del tarquimal / si no anem a coscorrons" (1840-41: I, 287). En el DCVB i en el DECat (VIII, 319) només figura tarquimar 'lloc on hi ha molt de tarquim', ${ }^{28}$ si bé Colomina (2017: 173) registra també en valencià tarquimal, però només amb el sentit de lloc on hi ha molt de tarquim. El sentit metafòric s'entén fàcilment, com en fangar, pel caràcter enganxós del fang o del tarquim, que dificulta els moviments o les accions.

Té també un caràcter col-lectiu i abundancial el sufix -ar en els substantius *clossar i *genibrar: "Anaben sis coixos, tots en closes, d'un poblet a un atre, y cansats de pegar cabotaes y ranclechar, s'asentaren baix d'un llidoner [...]. S'adorgueren els sis com a marmotes, y pasant per aquell closar uns que els coneixien..." (1837: III, 62), "So Chordi, com se coneix / que ya no té ferramenta / com la tenen els demés / y està feta un chenibrar / eixa boca de sarset" (1837: II, 201). Es tracta de creacions jocoses, no registrades en els diccionaris. La primera veu és derivada de clossa, variant valenciana de crossa amb canvi de líquida, i la segona deu estar relacionada amb geniva, tenint en compte que fa referència a la boca d'una persona sense dents, que només disposa de les genives. En aquest cas deu haver-se produït un encreuament entre els parònims geniva i ginebrar 'ginebreda', ${ }^{29}$ tenint en compte que el sufix -ar forma derivats collectius i abundancials, i s'aplica sovint a fitònims i a altres referents. ${ }^{30} \mathrm{~A}$ la persona esdentegada només se li veuen en la boca les genives, $i$, per tant, jocosament, en lloc de dentadura té només un conjunt de genives.

Es troba el sufix -al en adjectius indicadors de pertinença o relació: * pesetal (1837: I, 151), en penes pesetals, això és econòmiques, ${ }^{*}$ carabasinal (1840-41: I, 151), en llúpies carabasinals, això és en el cap o carabassa, amb la mateixa terminació que medecinals, aparegut poc abans en un text on l'autor contrafà jocosament el

en valencià. El registra Escrig (1851), i el podem trobar també documentat: "camp excelent de cultiu, poro camp sens amo, fet un perdut, un brossar frondós, per tindre-lo abandonat sos mateixos coltivadors naturals" (Faustí Barberà, Per a valencians, València, 1913, p. 24), per referència figurada al valencià.

${ }^{28}$ El DO, el DGLC, el DIEC i el DDLC no registren cap de les dues formes; en el DNV només tarquimar 'lloc ple de tarquim'.

29 Ginebrar, derivat col-lectiu i abundancial de ginebre. El DCVB registra ginebrar a Eivissa i ginebral en valencià, però la forma ginebrar és també coneguda en terres valencianes (Escrig 1851; Colomina 2017: 63).

${ }^{30}$ També es pot entendre com una homonimització de geniva al parònim ginebrar basant-se en el caràcter col-lectiu i abundancial del sufix -ar. 
llenguatge mèdic; **boual 'propi dels bous, boví: "tersera estasió boual" (1855: II, 16), per referència al tercer dia de "corregudes de toros" (1855: II, 16), "ganao [...] boual" (1863: 18); ;1 *segal (cegal) (1840-41: I, 299), *diarral 'diarreic' (1837: II, 60), *moñicotal (1837: II, 221), * grasiosal 'graciós' (1837: II, 137), * papafigal (1840-41: II, 144), per relació al periòdic El Papafigo, així com *rechensial i *desgobernal, formats per analogia de constitucional: "Asò no és chens constitusional, però rechensial $\mathrm{o}$ desgobernal" (1840-41: I, 330). Es tracta de mots no registrats en els diccionaris, sovint de caràcter jocós, creacions dels redactors d'El Mole.

\subsection{El suffix -alla}

El sufix -alla té caràcter col-lectiu i despectiu en +fadrinalla (1837: I, 135); ${ }^{32}$ en contalla (1840-41: I, 111) indica acció i efecte de contar, narració. Quant a faramalla, segons Coromines (DECat, III, 884), procediria del castellà, amb el sentit d'“embolicaire', 'conjunt d'embulls i coses aparatoses sense solta', i en català se li afegí el sentit de 'conjunt de genteta', per contaminació de feram. En el text d'El Mole es refereix jocosament als redactors del periòdic: "y casi tots coneixen a la faramalla llauraora que treballa en El Mole" (1837: II, 53); el documentem en altres textos valencians dels segles XVIII, XIX i XX amb els sentits de 'conjunt de genteta o de gent renouera', 'xicalla', i fins i tot 'conjunt dels ingredients d'un enema' (Martí 2006).

\subsection{El sufix $-a m$}

El sufix -am aplicat a radicals nominals té valor col-lectiu. Segons Moll (2006: 242), “indica multitud o gran volum". Duarte i Alsina (1986: 73) diuen que, a més del valor col·lectiu, "de vegades potser també intensiu" i que "s'aplica a radicals amb matrius semàntiques força diferents". En El Mole el trobem en: +costellam (1837: I, 207; III, 54), ${ }^{33}+$ fullam (1837: III, 107), ${ }^{34}{ }^{\circ}$ pardalam (1837: II, 58; 1840-41: I, 34). El DCVB registra pardalam 'multitud de pardals' en menorquí, en canvi, el DAg (VI, 43) el registra a València. Figura també en els diccionaris valencians del segle XIX

${ }^{31}$ L'adjectiu boval, boual o boal "s'aplica a certs gèneres de plantes, com la vinya i el vi" (DECat, II, 184), i substantivat designa un estable o corral de bous (DCVB, DECat, DAg, DGLC, DIEC, DNV, DDLC).

32 Es documenta ja al segle XVIII: "Hui corre una fadrinalla / que és vergoña nomenar" (Coloqui nou per a riure's de bona gana [...], compost per Pep de Quelo el de Paiporta, en este añ de 1753. Primera part, València, p. 2).

${ }^{33}$ Primera documentació de costellam en el DECat (II, 999) en Labèrnia (1839-40). El documentem ja a principis del segle XIX en el Coloqui del mestre Chusep: "y si no el deté ma mare, / em destrosa el costellam" (BMV, fons Serrano Morales, ms. 6781, p. 2).

${ }^{34}$ En el DCVB no es documenta fins 1885, i en el DECat (IV, 225) fins Verdaguer. El documentem ja als segles XVI i XVII: "Ítem dos pilars a cada costat del portal los quals pilars ab ses bases y capitells y pels cantells dels pilars ses motluretes ab sos candelers de fullams" (any 1517) (GómezFerrer 2002: 66), "Mes corona de poetes / poca sustància tindrà, / y a mos versos pareguda / fóra fruyt, fóra fullam" (any 1685) (Mas 1998: 111). 
(Escrig, EscLl, MGad). No el recullen el DGLC, el DIEC ni el DDLC, però sí el DNV.

\subsection{El sufix -ança}

El sufix -ança expressa acció i efecte, i actua com a nominalitzador de verbs de la primera conjugació. Forma noms abstractes. López del Castillo (2002: 52-53) afirma que actualment, "fora d'una sèrie de mots de la llengua d'ús", aquest sufix és substituï "per altres sufixos de derivació". En El Mole el trobem en mots habituals com desconfiansa (1840-41: II, 62) i ordenansa (1855, II, 181), i en altres on actualment hom prefereix altres sufixos en la llengua literària: comparansa (1837: II, 56), que en el DIEC i en el DNV figura com a forma secundària de comparació, $\mathrm{i}$ *contratanses 'tractes, contractaments' (1837: I, 215), no registrat en els diccionaris històrics ni normatius.

\subsection{EL SUFIX -ANTE}

El sufix -ante es troba en l'adjectiu *pillante (1840: I, 24, 96, 267), que funciona també com a substantiu per conversió gramatical, i en l'adjectiu *remendante. El primer fa referència als mals governants, astuts i sense escrúpols, que anteposen l'interés personal al col-lectiu. El segon es refereix als sabaters de vell: "el sombrero ya servix per a les ferramentes de un sabater remendante" (1837: I, 239), en castellà zapatero remendón. En remendante el sufix funciona com a adjectivador deverbal, del cast. remendar, mentre que pillante sembla un cas de sufixació parasitària per relació al castellanisme pillo. ${ }^{35}$ Es tracta, respectivament, de derivats dels castellanismes pillo i remendar, amb el sufix -ante, indicador de l'agent. El sufix agentiu -ante, corrent en l'antiga germania castellana, es mostra també molt productiu actualment en castellà en la nominació i adjectivació deverbal (veg. Lang 1992: 186-187, 206). El trobem, igualment, en diversos mots argòtics i col-loquials, sovint de caràcter pejoratiu, documentats en textos populars valencians dels segles XVIII, XIX i XX, com plaiante, calfante, tunante, redoblante, rapante 'lladre', etc. (veg. Martí 2006). ${ }^{36}$ Tot i que aquest sufix degué introduir-se en català amb mots castellans, posteriorment, ha estat aprofitat per analogia en la creació lèxica en valencià, com segurament és el cas de pillante i remendante, que no semblen ser coneguts en castellà.

35 Sobre el concepte de sufixació parasitària, veg. Seco (1970: 177-178), que, en la mateixa categoria, registra en Arniches golfante 'golfo', format "por influjo de mangante y tal vez de tunante".

${ }^{36}$ Aquest sufix, present en diversos mots usats en valencià, degué contribuir a la popularitat del terme afectiu mante (reducció del castellà amante) en valencià (veg. Martí 2015: 79-80). 


\subsection{El sufix -ària}

El sufix -ària es troba en els substantius *anticuària (1837: II, 119, 163, 165) i *herbolària (1837: I, 217). ${ }^{37}$ López del Castillo (2002: 72) es refereix al sufix -ària formador de noms femenins "per substantivació de la forma femenina de l'adjectiu [...], significant 'art, ciència, empresa, espècie, establiment, institució'"', com en estatuària, funerària, veterinària, etc., però en el cas d'herbolària i antiquària sembla més aviat que caldria partir dels substantius herbolari (fem. herbolària) i antiquari (fem. antiquària), ${ }^{38}$ respectivament, que designen càrrecs o oficis. ${ }^{39}$

\subsection{El sufix -dera}

El sufix -dera forma, a partir de radicals verbals, substantius amb la característica semàntica d'acció i efecte (bullir - bullidera, bufar - bufadera) (Cabré 2008: 749; Gramàtica de la llengua catalana 2017: 399). Així, partint del verb adormir es forma el substantiu *adormidera 'adormiment, acció i efecte de dormir, d'estar adormit': "tot lo que convé saber al poble, y, en fi, tots los michs de eixir-ne de una de la adormidera en què està" (1837: I, 302), en el text, figuradament, en relació amb la ignorància que tenen els pobles sobre la manera de fer front als carlins. MGad inclou el substantiu dormiguera, com a sinònim de sonera i sonaguera 'sueño, soñera, sonariera: gana irresistible de dormir' ${ }^{40}$ En el DCVB també es registra

37 El DNV registra el masculí herbolari ‘herboristeria'. EscLl i MGad recullen herbolària 'tienda donde se venden hierbas medicinales'. Es documenta també en altres textos valencians dels segles XIX i primera meitat del XX, ex., "la dona és una herba mala..., / encara que tots els hòmens / volgueren tindre herbolària" (Antoni de Cidón, Les beates, València, 1909, p. 2), “-Però, reché, así què fiques? / [...] -És un secret d'herbolària / para vivir largos años" (Maximilià Thous, Faust Hernández: A la vora del riu, mare..., València, 1919, p. 14), "-iChitana! / [...] y pimpollet!, y girànio!,/ y tomillo!, y herbasana!, / y sinc sèntims de poleo!, / y ditet!, y calaguala!, / y entre requiebros y flors, / deixen huida la herbolària" (Faust Hernández Casajuana, ¡Che, ves a patinar! Falla del carrer de la Mar 1914, València, p. 3), en aquest cas la rima asonant mostra que l'accent se situa sobre la primera $a$, i no sobre la $i$. També referit a les herbes i plantes medicinals: "TONA: -Qu'és asò, che? / SENTO: -Un regalet. / TONA: -Herbolària? / SENTO: -Pa l'enfit / estes herbes bollidetes...; / estes floretes d'así, / pa la migraña [...]; estes raïls [...]" (Rafel Martí Orberà: Bodes d'or, València, 1927, p. 17). Així mateix es troba la variant harbolària, explicable per assimilació a la vocal tònica, juntament amb la tendència occidental a obrir la $e$ de la síl-laba inicial (Diàlogo reflexiu entre dos amics de la veritat..., València, 1827, p. 9; Almanaque de Las Provincias para el año 1896, p. 104).

38 Sense descartar una possible interferència del castellà, on registrem anticuaria 'ciencia de anticuarios' al darrer quart del segle XVIII (CORDE, NTLLE) i herbolaria 'botánica aplicada a la medicina' figura en el DRAE (ed. 1925) com a forma antiquada.

${ }^{39}$ El mateix López del Castillo (2002: 70) inclou -ari (-ària) com a sufix que "forma noms que designen persones, càrrecs, oficis, estats", com antiquari i herbolari. Així, l'antiquària seria l'art o l'ofici propi de l'antiquari, i l'herbolària l'art o la ciència de l'herbolari.

${ }^{40}$ Aquest diccionari registra sonaguera, i no soneguera, que seria la forma esperable d'acord amb la doble sufixació eg + era (veg. Colomina 1995: 88). En canvi, en El Mole apareix soneguera. Igualment, en el DCVB, soneguera, i no sonaguera. Però sonaguera també es troba en textos valencians: "y parlant de llits y de sonaguera" (Constantí Llombart, El pare Mulet. Semanari 
dormiguera 'ganes de dormir' en valencià i balear. ${ }^{41}$ Així mateix, hem sentit en valencià el substantiu dormidera amb el sentit d"'acció i efecte de dormir', com adormidera.

\subsection{El sufix-dura}

En el sufix -dura es troba tant la conservació de la consonant dental com la seua elisió darrere de $a$. Es tracta d'un sufix que forma noms femenins a partir de verbs, dels quals expressa l'acció i l'efecte (cfr. López del Castillo 2002: 156): afechidura (1837: I, 380), *contadura 'acció de contar (un conte)' (1855: I, 141), *desgobernaüra: "el gobern de les desgobernaüres" (1840-41: I, 330), 'empreñaüra (1840-41: I, 286), * posadura (1837: II, 59), *soterraüra (1840-41: I, 319), tallaüra (1837: II, 120), trovaüres (1837: I, 239).

\subsection{El sufix $-e a$}

El reflex del sufix llatí -ITTIA presenta sempre la forma -ea, com és habitual en valencià. ${ }^{42}$ Origina noms femenins a partir d'adjectius; indica qualitat, condició o estat. ${ }^{43}$ Exs. baixea (1837: I, 11), enterea (1837: II, 72), fortalea (1837: I, 46), franquea (1840-41: II, 144), grandea (1837: II, 163), *honradea (1837: II, 267), *insulsees (1837: II, 372), pobrea (1840: I, 20), *ridiculea (1837: II, 19), riquees (1840-41: I, 15), vellea (1837: II, 70).

\subsection{El sufix -ència}

Notem el sufix -ència que forma noms femenins amb el significat de 'condició de', 'qualitat de' en el substantiu, no registrat en les fonts consultades, *burrènsia 'ignorància, malaptesa, bestiesa' (1855: I, 309), derivat del castellanisme burro, per referència als mals governants.

impolític, y Bou Solt, València, 1877, p. 116), "y pega cabotaes de tranquila sonaguera" (Gil Barullo, La perla de Alberic, València, 1918, p. 3), “Lo que té ara Micalet / és... que té una sonaguera!” (Llibret de la falla dels carrers de Espartero y adyacens. Any 1928, València, p. 4). La a pot explicar-se per analogia d'altres derivats de son, com sonada, sonadeta, per analogia d'altres substantius deverbals amb la terminació -a(cons.)era (ploradera, xarrera, cacera, fartera...), o fonèticament per dissimilació entre vocals anteriors $e-e ́ s a-e ́$, o potser més aviat per la combinació dels factors fonètics $\mathrm{i}$ morfològics.

${ }^{41}$ Duarte i Alsina (1986: 101) consideren que el sufix nominalitzador de verbs -era "presenta una variant dialectal, a les Balears, en -guera i -iguera amb verbs de la segona i de la tercera conjugació". Veiem, però, que també es coneix en valencià.

${ }^{42}$ Martines (2000: 288-289) afirma que "la var. -ea és la més habitual al PV a les hores d'ara, si més no, en les comarques centrals i meridionals", i a pesar del clar predomini d'aquesta forma, dóna compte d'algunes mostres de la variant -esa en textos valencians dels segles XVIII, XIX i XX.

${ }^{43}$ Per a la història d'aquest sufix, vegeu Moll (2006: 255) i Duarte i Alsina (1986: 93-94). En català antic la forma -ea tenia una major extensió geogràfica que en l'actualitat, on es conserva en valencià, i, segons Duarte i Alsina, "en certs casos a les Illes". 


\subsection{El sufix -ensos}

*Ateniensos (1837: I, 32, 1837: II, 139), per atenesos, és una adaptació del castellà atenienses, adaptant analògicament el sufix castellà -enses en -ensos, seguint el model del català (cfr. cast. franceses, ingleses / cat. francesos, anglesos).

\subsection{Els sufixos -eny, -enc}

Amb referència als naturals de la comarca valenciana de la Ribera es troba en $E l$ Mole el gentilici plural *ribereñs (1837: I, 246), derivat amb el sufix -eny. En el DCVB només riberenc 'pertanyent a la ribera o vora de la mar o d'un riu', documentat en L'Atlàntida de Jacint Verdaguer, i 'nadiu de la Ribera (del Xúquer, de l'Ebre, etc.)', sense documentació. El DECat (VII, 312) també registra només l'adjectiu riberenc, documentat en el mateix text de Verdaguer i en Miquel Alcover. Igualment, el DO, el DGLC, el DIEC i el DNV només recullen riberenc, amb tots els seus significats. Cal tenir en compte, però, que el sufix -eny, -enya també s'utilitza en català en la formació de noms gentilicis (cfr. Duarte i Alsina 1986: 114; López del Castillo 2002: 175), en topònims espanyols i en els que ens han arribat a través d'aquesta llengua, però també en diversos gentilicis del País Valencià, com alzireny, almussafeny, naquereny, etc. (Rull 2004: 260-261). De fet, l'adjectiu ribereny, riberenya es documenta en textos catalans dels segles XIX i XX (CTILC) i el recull el DDLC com a sinònim de riberenc. Així mateix, Escrig (1851) inclou ribereny en el seu diccionari, si bé EscLl i MGad el substitueixen per riberench. ${ }^{44}$ Probablement els diccionaris normatius catalans han evitat ribereny pel fet de considerar-lo un calc del castellà ribereño, sobretot tenint en compte que, segons comenta Rull (2004: 260), "el sufix espanyol -eñ és molt més rendible que el corresponent català -eny". ${ }^{45}$

\subsection{Els sufixos -er, -ero, -era}

Com ocorre actualment en valencià, es troben en El Mole el sufix genuí -er i el castellanitzant -ero.

${ }^{44}$ Evidentment, en altres textos valencians es llegeix riberenc, com en Els moneros de Francesc Comes: “-Señores, aquí estoy yo. / -Parese usté un riberenc (Tots se rihuen)" (València, 1919, p. 14), segurament, un rústic de la Ribera, la qual cosa provoca les rialles de la concurrència urbana. El sufix -enc també apareix en El Mole, però amb altres radicals, com a gentilici en albuferenc (184041: I, 34), i amb caràcter abundancial en famolenc (1837: I, 48). Duarte i Alsina (1986: 114) es refereixen a les formes on es produeix una vacil-lació entre -enc i -eny, com ara alzinenc i alzineny.

${ }^{45}$ No figura tampoc -eny entre els sufixos usats en la formació d'adjectius a partir de noms en Cabré (1994: 53, 2008: 757), que recull -enc, però no -eny. En canvi, la Gramàtica de la llengua catalana (2017: 401-402) de l'IEC sí que inclou -eny, -enya entre els sufixos adjectivadors, usats per a formar adjectius de relació i gentilicis (caribeny, caribenya), i, igualment, Bruguera (2001: 349) registra el sufix -eny, -enya (del llatí -IGNUS, -A, -UM) en la formació d'adjectius de matèria i gentilicis. 
Duarte i Alsina (1986: 115) creuen que el sufix -ero, estés al País Valencià, $\mathrm{s}^{\prime}$ ha de considerar sovint un mossarabisme, ${ }^{46}$ i afegeixen que "en certs casos [...] es pot establir un matís distintiu entre les formes -er i -ero, coexistents en una mateixa contrada, en el sentit que -ero és més afectiu i depreciatiu i -er és més objectiu i noble". Ara bé, com apunten Casanova (1995), Martines (2000: 294-306) i Rull (2004: 172), la forma -ero té segurament més a veure amb l'aragonés i el castellà que no amb el mossàrab; ${ }^{47}$ si bé Casanova i Martines coincideixen amb Duarte i Alsina a l'hora d'atorgar al sufix -ero un caràcter afectiu. ${ }^{48}$

En El Mole trobem -er en noms d'oficis i professions, tant en oficis tradicionals: artiller (II, 75), barber (1837: I, 67), berguer (aixo és, verguer) (1840-41: I, 235), blanquers (1837: II, 116), bodegoner (1837: II, 308-309; 1840-41: I, 131), botiguers (II, 365), cadirers (II, 365), campaner (1863: 35), carboner (II, 278; III, 8), carreter (1864: 404), cuiners (II, 365), culliter (1837: II, 201), cuquiller (1837: I, 263), ${ }^{49}$ dolsainer (1840-41: I, 185), mariner (1840-41: I, 265), femater (1837: III, 103), foguerer (1837: I, 4, 91, 315), pastiser (1837: II, 365), pedrapiquer (1837: I, 334), pellers (1837: II, 380), porter (1837: II, 254; 1840-41: I, 247), pregoner (1840-41: I, 283), sabater (1837: II, 94), sucrers (1837: 95), taberner (1837: I, 352), tintorers (1837: II, 116), velluter (1837: I, 379), com en altres de documentats més recentment, com bagachers (184041: I, 11), bolichers (1837: I, 378), ' ${ }^{\circ}$ ullerer 'fabricant o venedor de culleres' (1837: I, 57), ${ }^{\circ}$ estanquer (1840-41: I, 99), ${ }^{\circ}$ quincaller (II, 365) $\mathrm{i}$ *cheremiter (1840-41: I, 185)..$^{50}$

46 Coromines (DECat, VII, 425-426) ja considerava un mossarabisme el substantiu romero 'romani', usat per Eiximenis com a terme valencià.

47 Així mateix, Veny $(2003: 33,155)$ considera que el sufix -ero, "d'una certa freqüència" en mallorquí, és de procedència castellana.

${ }^{48}$ Casanova posa en relació el sufix -ero amb l'arrelament en valencià de la -o final en el sistema expressivoafectiu, present en hipocorístics i en apel-latius amb -o final. Afegeix Casanova que aquest sistema "elimina el sufix -er davant -ero: fallero, pardalero, tripero, mongero,... tots usats des del segle XVII en el llenguatge popular". Martines recorda que el sufix -ero no és exclusiu del valencià sinó que es troba també "en altres regions de l'idioma", el relaciona amb la propagació de - $o$ en català, i considera que l'èxit d'aquest sufix potser s'ha d'interpretar des d'una perspectiva ampla, "que combine els factors externs, derivats de la influència aragonesa i castellana" i altres "factors de caire intern".

${ }^{49}$ Variant de coquiller, amb tancament de la $u$ àtona en contacte amb les consonants velars $\mathrm{i}$ davant la $i$ de la sílllaba següent. La forma cuquiller es documenta ja al segle XVIII en un poema valencià (Martí 2013: 244). Segons el DCVB, coquiller és un derivat de coca, "probablement deformació de coqueller". Coromines (DECat, II, 791) creu que coqueller / coquiller serien derivats d'un "diminutiu o hipocorístic coquella / coquilla per 'panet", i afegeix que coqueller és usat a Tortosa i coquiller a València. Cal dir, però, que coqueller també es documenta en valencià al segle XVII: "-Altres paren en macips; / altres, en abaixadors. / -Altres se fan coquellers" (Ferrando 1995: 273), "Punyalades a un fadrí coqueller y a una dona" (Escartí 1999: 261).

50 Si bé xaramita 'dolçaina' es documenta ja en el Tirant lo Blanch (DCVB; DAg, VIII, 278; DECat, IX, 502), el derivat xaramiter, que el DCVB registra en valencià meridional, s'hi presenta en aquest diccionari sense documentació, i no és registrat en els altres dos, com tampoc en el DIEC. El DCVB i el DECat recullen també les variants palatalitzades xeremita, xerimita i xirimita, però no la variant xeremiter del derivat. Cfr. xaramiter en textos alacantins i il-licitans de finals del segle XIX: "el sèlebre charamiter Simeon" (El Bou, Elx, 1885, núm. 33, p. 2), "Y al charamiter, que vecha de anar 
Referit a persones i animals, pot assenyalar, així mateix, activitats, conductes o condicions: ambuder (1837: II, 150), cucs filaners (1837: I, 70), *dona conillera 'dona molt fecunda' (1840-41: I, 285), ' frarer (1837: I, 281), ' frarera (1837: II, 270), gos perdiguer (1837: I, 128), ' goset arbelloner (1863: 143), ${ }^{51}$ pasachers (1837: I, 87), +roders (1837: II, 200). Designa també fitònims: albercoquer (1840-41: I, 70), *braser 'esbarzer' (1837: II, 200), objectes, sovint amb un caràcter col-lectiu, de continent o instrumental: arer 'erer' (1864: 240), bolquers (1837: I, 311), calser (1837: I, 107), pedrer (1837: II, 262), tinter (1837: II, 134), llocs, amb la idea de continent: colomer (1837: I, 174), +escudeller (1840-41: I, 99), femer (1837: II, 248), graner (1863: 73); adjectivador de substantius indicant relació: meler (1837: II, 204). Té també valor collectiu en *centener, amb el sentit de 'centenari': "Segons les descripcions impreses que hi à de dites festes. [...] Però no sabem si al cumplir-se el centener de alguna de elles [...] (1837: II, 356).

Referit a oficis i a condicions o atributs de persones, en alguns noms d'origen castellà hom ha adaptat el sufix -ero castellà en -er: * camarillers (1837: I, 89), * prisioner (1837: I, 260; II, 202), * reposters (1837: II, 365), sombrerer (1837: II, 365; 1863: 22). Aquest fet sembla un indici de la vitalitat que, a pesar de la concurrència de la forma -ero, continuava tenint el sufix -er en valencià al segle XIX. Igualment, i de manera jocosa, hom transforma el cognom castellà Landero en Llander o Llanterner: "Però el sr. Landero o Llander o Llanterner" (1837: II, 42). Així mateix, en la relació irònica entre ligeros, cos militar, i l'adjectiu llauger veiem la consciència de la diferència entre un -er propi i un -ero castellà: "Pos en cuant a la edat, no dic res. Rosí hi à que serví en coraseros cuant a la guerra de Napoleon, y ara l'à admitit, sinse ducte per a que servixca en ligeros; vechen cuan llaucher estarà el pobre rosí" (1837: I, 363).

El sufix -ero apareix en El Mole en substantius i adjectius que en castellà tenen una forma similar, i que hem d'entendre com a procedents d'aquesta llengua: *apostadero (1837: III, 11), *del brasero (1863: 79), *bullanguero (1837: II, 324), *caminero (1864: 240), compañero (1837: II, 206; 1840-41: I, 319), +embustero (1837: II, 326, 1840-41: II, 53), *pandillero (1840-41: I, 211), *peluquero (1840-41: I, 264), *reverbero (1837: I, 247, II, 235), +salero 'gràcia natural' (1837: II, 165), *trifulquero (1837: II, 324); igualment, en la forma adaptada en la consonant inicial +lletrero (1837: I, 89, II, 167, 309), o * morrondanguero (1870: 38), cast. morondanguero, derivat de morondanga, que els redactors d'El Mole adapten en morrondanga..$^{52}$ Igualment, cebero, derivat de ceba, té un equivalent en el cast. cebollero (de cebolla); el

en cuidao, perquè estes chiques el tornen tonto" (El Cullerot, Alacant, núm. 31, 1897, p. 3). Sobre xaramita, veg. també Martí (2017).

51 Varietat de gos, en valencià (DCVB; DECat, II, 581; Martí, 2011).

${ }^{52}$ No són rares les fluctuacions entre la bategant $i$ la vibrant. Vegeu, a aquest respecte, Martines (2000: 225-240). 
documentem en el topònim de l'Albufera de València Mateta dels Seberos (1863: 43), això és, dels Ceberos. ${ }^{53}$

Algunes veus tenen en català formes corresponents amb -er, però en $E l$ Mole només es mostren en la forma -ero, coincident amb el castellà: armero (1837: II, 319), arriero (1837: II, 238, III, 121), probablement castellanisme arrier (DECat, I, 424), barqueros (1863: 43, 1864: 278), carabinero (1837: I, 330; II, 191), cartero (1837: III, 13), cochero (1837: II, 140), farolero (1837: I, 89), ${ }^{54}$ florero, ${ }^{55}$ ibero (1837: I, 374), misionero (1837: II, 151, 1840-41: I, 474), peseteros (1837: II, 254).

En altres mots es troben en variació ambdós sufixos, sense que s'observen diferències semàntiques remarcables entre l'ús de l'un o de l'altre. Es tracta de lexemes compartits pel català i el castellà, però amb una forma diferent en el sufix propi de cada llengua: caballeros (I, 28; 1840-41: I, 230) - caballers (I, 91; II, 11; III, 24; 1840-41: I, 118), més usada la segona forma; fullero (I, 91; II, 101, 326; 1840-41: I, 105) - fuller (1837: I, 382), ${ }^{56}$ tartanero (II, 170, 223, 232; III, 25; 1840: I, 38) - tartaners (II, 231), en canvi en aquests casos més usada la primera, en -ero; torroner (1855: I, $256,342)$ - torronero $(1863: 82,83)$, en sentit figurat, com el cast. turronero 'el que saca provecho de un cambio político en que ha tomado una parte política' (Gaspar y Roig 1855, en NTLLE). ${ }^{57}$ També conviuen els sufixos -ero i -er en el castellanisme incheniero (1864: 162), incheniers (1837: II, 302).

No és tan habitual trobar el sufix -ero en mots que semblen creacions pròpies, tot i que amb la terminació $-o$, i que en castellà coneixen alternatives diferents. Són indicadors del grau d'incorporació d'aquest sufix en valencià, usat

\footnotetext{
${ }^{53}$ En valencià es coneix ceber o cebero, a referit als venedors de cebes (Escrig 1851, DNV), encara que el DCVB només recull ceber amb aquest sentit a Mallorca.

${ }^{54}$ En aquest mot, segons el DCVB, "és freqüent la forma masculina farolero, la qual indica la procedència castellana del mot"; Coromines (DECat, III, 882) també opina que farol "ha obtingut més o menys acceptació en terres valencianes, suposo per contagi castellà".

${ }_{55}$ Cfr. "pos si la duen arreglaeta [la caeneta] per damunt del chaleco, pareix un altaret, una capelleta apañada de florero" (1837: I, 104), “Lo que més m'agradà de tot fon el dosel del rey, la taula y les caïres, y les arañes de florero. Que boniques estaben!" (1837: II, 95). En castellà, florero 'el tiesto en que nacen o se ponen las flores', 'el que trata en flores de mano, las hace o las vende' (Diccionario de Autoridades, en NTLLE); en català, segons el DCVB, florer 'venedor de flors', 'gerro o vas especial per a tenir-hi flors'. En els textos de més amunt procedents d'El Mole florero té, però, un sentit diferent, per referència a la persona encarregada de fabricar i posar adornaments, sobretot amb motiu de les festes, en carrers, esglésies, altars, cases, o carros triomfals, així com de preparar el vestuari festiu, tal com el trobem en altres textos valencians dels segles XIX i XX, i com el recullen els diccionaris d'Escrig (1851), EscLl i MGad, sota les formes florer i florero. Sobre aquest sentit de florero, diferent al que recullen els diccionaris històrics i normatius en català (florer) i en castellà (florero), vegeu Martí (2017).

${ }^{56} \mathrm{El}$ mot fuller no figura en el DO, en el DGLC, en el DIEC ni en el DNV, i el DCVB, que el registra sense documentació, el considera pres del castellà fullero. Coromines (DCECH, II, 973975; DECat, IV, 224) valora la possibilitat de considerar el cast. fullero un catalanisme, però reflexiona també sobre altres alternatives, i no acaba decidint-se per una proposta etimològica clara. Quant al valencià fuller, el registra en Sanelo i en Escrig, i no descarta la possibilitat "de que tenga arraigo en el catalán de Valencia".

${ }^{57}$ Coromines (DCECH, V, 703) veu probable que el castellà turrón siga un catalanisme.
} 
en la formació de nous noms. És el cas de l'adjectiu cosero, a referit a un animal que tira guitzes (cast. coceador): "li fa aparellar l'aca cosera" (1840-41: I, 307), "al cap y al fi, burros són tots, llevant alguns coseros mal intensionats y sorros consumats" (1855: II, 10); usat també en sentit figurat: "Però és una burralitat molt cosera y torpe anar a la palla, y no al gra" (1855: II, 44), i animal cosero com a insult a un poca-solta o capsigrany (1855: II, 75). ${ }^{58}$ Mot derivat de coç o coça 'guitza'.

Es troba també el sufix -ero en el substantiu *pilotero (1840-41: I, 34), per referència a un ocell de l'Albufera de València. No figura en el catàleg d'Orellana (1795), però Vidal (1995 [1851]: 33) incloïa dos ocells d'aquest nom: Pernis apivorus, val. pilotero, cast. halcón abejero, ${ }^{59}$ i Circus aeruginosus, val. pilotero, cast. arpella. ${ }^{60}$ Rafael Pardo (Vidal, 1995: 5-6) en el seu comentari al catàleg de Vidal designa aquestes aus de rapinya amb noms diferenciats. El primer Pernis apivorus, cast. halcón abejero, hi és anomenat en valencià pilot, ${ }^{61}$ i el segon, Circus aeruginosus rep en castellà el nom d'aguilucho lagunero i en valencià arpellot de marjal. Luis Pardo (1942: 145) incloïa dos ocells diferents amb el nom val. de pilotero: Circus c. cyaneus (L.) (cast. ave de San Martín) i Circus pygargus (L.) (cast. cenizo). Momblanch (2003 [1960]: 207) registra també amb el nom de pilotero dues aus diferents: Cyrcus c. cyaneus i Falco apivorus (cast. halcón abejero). Per la seua part, Rosselló i Verger (1995: 91) recull el Circus aeruginosus L. amb els noms valencians de pilotero i arpellot, que hi correspondrien al "nom català normatiu" arpella. Per tant, segons els diferents autors, el nom pilotero (en algun cas, pilot) és aplicat fins a quatre ocells distints.

Cal destacar la presència en El Mole d'alguns vocables formats amb el sufix -er(o) no inclosos en els diccionaris catalans ni castellans, i sovint no enregistrats tampoc en les fonts escrites consultades, almenys en les anteriors cronològicament, amb la qual cosa ben bé es podrien considerar com a creacions dels redactors d'aquest periòdic. Són una prova més de la popularitat d'aquest sufix a l'època.

En aquest sentit, el sufix -ero com a adjectivador de substantius i indicant relació apareix en *moleros, per referència als redactors d'El Mole: “Mos han dit que un home que viu en Valènsia ha dit que donaria un milló per poder amolar

${ }^{58}$ El DCVB registra cosser (o cocer) 'que tira coces' en mallorquí i menorquí, sense documentació, però, com veiem, el feien servir també els redactors d'El Mole, amb la terminació -ero.

${ }^{59}$ Sobre aquest ocell informava que "el adulto es raro en la Dehesa, mas el joven es muy común".

${ }^{60}$ Afegia Vidal que és "sedentario, y muy abundante en las orillas del lago". EscLl es limita a repetir la informació de Vidal en els dos ocells del mateix nom, sense incloure les denominacions llatines. El mateix es troba en MGad, si bé aquest canvia la forma pilotero per piloter.

${ }^{61}$ Aquesta denominació, pilot, es troba també en el DNV: “au de presa (Pernis apivorus), d'uns 56 centímetres, amb el plomatge marró pàl-lid, especialitzada en la detecció de bucs d'abelles silvestres i vespers, dels quals consumix la mel i les larves'. No figura en el DGLC ni en el DIEC. 
als moleros" (1837: II, 107), fent un joc de mots amb amolar, ${ }^{62}$ "també s'aseguraba que El Mole no eixia ya perquè els moleros s'habien rebordonit" (1840-41: I, 373), ${ }^{63}$ i en papafigueros (1840-41: II, 37, 106), referit, igualment, als redactors d'El Papafigo, un dels noms que pren el periòdic El Mole en la segona època.

L'adjectiu *charlatanero sembla una creació puntual, amb el sufix -ero, per permetre la rima amb farolero: ${ }^{64}$ "De qui podràs ya fiar-te, / si menistres faroleros, / diputats charlataneros / es conchuren pa asolar-te!" (1837: I, 89), fora d'aquesta situació fan servir charlatà (I, 90). ${ }^{65}$

El substantiu * polvillero (1837: II, 74), amb el sufix -ero indicador d'agent, designa una persona que pren tabac en pols o polvillo. ${ }^{66}$ Els mals polítics i governants, que només cerquen el profit personal, són anomenats satíricament *ambisioneros i *mameros (1855: I, 121-122), i, igualment, els partits polítics oportunistes són *milloneros (1855: I, 190). En el mot *lliberalero 'fals liberal' (1870, 207) el sufix -ero afegeix un matís despectiu que no està present en lliberal.

Resulta curiós el substantiu ${ }^{*}$ jefero, derivat del castellanisme jefe, ${ }^{67}$ amb el sufix -ero, designador en aquest cas de lloc, en concret en el text una oficina o administració política: "Més cuidao tinc yo de no anar raere de un pifiente cosero que de ficar un negosi interesant y urchent en una audiènsia, en un jefero polític, en una capitania cheneral, en una aduana o en un ministeri" (1837: I, 105).

El sufix -era forma fitònims en escursonera (1837: I, 157; II, 44), derivat d'escurçó, variant d'escorçó, indica llocs o objectes en pastera (1837: II, 237), tipus d'embarcació, coixinera (1837: I, 368) o el castellanisme 'rinconera (1837: II, 319), assenyala ofici en llavaneres (1837: II, 294); forma noms col-lectius a partir d'altres noms en garbera (1837: I, 173), en el castellanisme *alera (1837: II, 144), o en l'aragonesisme ${ }^{*}$ femera (1837: II, 60), ${ }^{68}$ funciona com a nominalitzador de verbs en +fartera (1837: I, 153, 384). Combinat amb el sufix -eg, forma noms femenins derivats d'altres noms: +soneguera (1840-41: I, 88). ${ }^{69}$

\footnotetext{
${ }^{62}$ Cfr. el joc de mots paronomàsic per repetició del mateix lexema, amb variacions en la forma: "Mole, molero, molut, / molent mos vols amolar; / mol, y te faran pasar / per lo estretet d'un ambut" (1840-41: I, 56-57).

${ }^{63}$ I en femení, en l'adjectiu molera, amb un sentit similar: "la redacsió molera" (1837: III, 7).

64 També hi ha canvi en la terminació de macarró, transformat en macarrí (1855: I, 191) per la rima: "ballarins" $\mathrm{i}$ "macarrins".

65 Segons el DCVB, xarlatà és un castellanisme; en canvi, Coromines (DECat, IX, 514) el creu procedent de l'italià ciarlatano; és admés per Fabra $(1917,1932)$, que també el considerava un italianisme, i en el DIEC, però no en el DNV.

${ }^{66}$ En castellà es registra polvillo, però no polvillero. El castellanisme polvillo 'tabac en pols' es documenta en valencià als segles XVIII i XIX.

${ }^{67}$ En El Mole es llegeix gefe (1837: I, 223, 261; II, 69), xefe (1837: I, 32) i la forma de consonantisme adaptat quefe (1840-41: I, 128, 253). Sobre l'adaptació històrica de la /x/ castellana en /k/ en català, vegeu Veny (2006: 33-60).

68 Sobre femera, vegeu Martí (2012: 145).

${ }^{69}$ Valencianisme, segons el DCVB i el DECat (VIII, 67).
} 


\subsection{El sufix -eria}

El sufix -eria naix de la combinació dels sufixos -er i -ia (veg. Duarte i Alsina 1986: $76,82,94)$ i s'utilitza, entre altres funcions, en la formació de noms indicadors de lloc, com peixcateria (1837: II, 268), i amb caràcter col-lectiu, com el fan servir els redactors d'El Mole en el substantiu *segueria 'conjunt de cecs' (1864: 204).

\subsection{El sufix -et, -eta}

El sufix -et, a més del seu contingut diminutiu, assenyala sovint una valoració expressiva o emotiva de caràcter subjectiu. Amb substantius, per ex., caset (1837: I, 111); en castellanismes substitueix el sufix de la llengua d'origen: sombreret (1837: II, 323), *condet (1840-41: I, 281), derivat de conde (1840-41: 281). En noms propis pot tenir un caràcter burlesc: Felipet (1840-41: I, 4), és a dir, el rei francés Lluís Felip (1840-41: 5). Es troba també en adjectius: nuets (I, 296), primeret (184041: I, 13, 293), dretets (1840-41: I, 351), en enumeracions: "que se hu tenien tan cregudet, tan caladet, tan maduret..." (1837: II, 318), en adverbis: enjornet (1837: II, 5), dretet: "mouen dretet al portal de la Reina" (1840: I, 38), aballet (1837: II, 157), claret claret (1837: II, 93), amb repetició intensiva de l'adverbi, i en locucions adverbials: a l'instantet (1837: I, 234), en seguideta (1837: I, 264; II, 24, 160).

Hi ha doble sufixació en *palleteta (1863: 87; 1864: 266) i en l'adverbi *aspayetet (1864: 250), i, unida a la lexicalització, en *cuetet $(1870,171)$, nom d'un ocell, ${ }^{70}$ que trobem en reculls ornitològics referits a la Plana: Castany (2012: 97) l'identifica amb la Motacilla flava, i Sanahuja (2003: 139) amb la Motacilla alba.

\subsection{El sufixos -edat, -etat}

El sufix llatí vocal + TATE presenta en català una doble solució: hereditària $-d-$, i cultista -t-. Forma substantius de qualitat a partir d'adjectius. Duarte i Alsina (1986: 91-92) assenyalen la dificultat d'establir-hi una norma explícita en la distribució de les variants. Amb tot, indiquen que "es combinen amb -edat els radicals acabats en /t/, en /ls/ i en /š/ i els radicals monosílllabs acabats en /k/" , i "es combinen amb -tat els radicals acabats en -i, llevat dels acabats en -ani i -geni, [...] i els radicals acabats en /ás/ (escassetat) o els radicals monosíl·labs en [w] (novetat)".

En El Mole es troba sempre la forma -etat, tant en els lexemes que s'ajusten a la segona norma descrita (novetat, 1837: I, 158) com en els que, segons la primera norma, haurien de construir-se amb -edat (buidetat, falsetat, fluixetat, sequetat).

\footnotetext{
${ }^{70}$ El DCVB, el DECat, el DGLC, el DIEC i el DNV registren el femení cueta, que designa diferents espècies d'ocells, derivat de cua.
} 
Aquesta és també la forma del sufix que es llegeix habitualment en els textos i diccionaris valencians d'aqueixa època. ${ }^{71}$

*buidetat (1837: I, 167). En el DCVB buidedat 'buidor', com a mallorquí, que és també l'única forma registrada en el DECat (II, 330), en el DO, en el DGLC, en el DIEC i en el DNV.

falsetat (1837: I, 153, 1855: II, 200). El DCVB registra actualment la realització -etat a València i Barcelona, i -edat només a Mallorca. Amb tot, el DIEC només inclou falsedat; el DNV i el DDLC afegeixen també, com a forma secundària, falsetat. De fet, falsetat es documenta ja en Ramon Llull (DCVB; DECat, III, 870). Aquesta és també la forma que trobem habitualment en els textos i diccionaris valencians del segle $\mathrm{XIX}^{72}$ a diferència de la major part dels diccionaris del Principat, que inclouen només falsedat (Esteve, Belvitges, Juglà 1803-05, Labèrnia 1839-40, DCCLFI, Saura 1878, Bulbena 1905, DO, DGLC, Vallès 1927), ${ }^{73}$ encara que en alguns diccionaris catalans del segle XX apareix només falsetat (Fiter 1913, Rovira i Virgili 1919).

*fluixetat (1837: I, 167). El DCVB, el DECat (IV, 57), el DO, el DGLC i el DIEC només registren fluixedat; en el DAg (IV, 70) fluxedat. El DDLC inclou fluixedat, com a forma principal, i fluixetat com a secundària. El DNV també les inclou totes dues, com a formes secundàries de fluixesa. Els diccionaris valencians del segle XIX (Escrig 1851, EscLl i MGad) registren només fluixetat, i el primer també fluixea. En canvi, els diccionaris de Catalunya i les Illes del segle XIX només registren fluixedat (Esteve, Belvitges, Juglà 1803-05, Labèrnia 1839-40, Saura 1878), fluxedat (DCCLFI, Figuera 1840), fluxedad (Febrer 2001, Amengual 1858-1878); igualment, al segle XX, en el diccionari Pal-las (Vallès 1927), fluixedat, i en Bulbena (1905, 1919) fluxedat, però Rovira i Virgili (1919) registrava, juntament amb fluixedat, com a forma secundària, fluixetat, i Fiter (1913) només fluixetat.

La forma sequetat (1837: I, 374) es documenta ja en Ramon Llull (DCVB), tot i això no es registra en el DO, en el DGLC ni en el DIEC; el DDLC i el DNV la inclouen com a forma secundària de sequedat. Els diccionaris d'Escrig (1851), EscLl i MGad registren només sequetat, com en els textos valencians dels segles XVIII, XIX i primer terç del XX; en canvi, els diccionaris del Principat i les Illes recullen únicament sequedat (Esteve, Belvitges, Juglà 1803-05, Labèrnia 1839-40, DCCLFI, Figuera 1840, Saura 1878, Bulbena 1905, 1919, Fiter 1913, Rovira i Virgili 1919, Vallès 1927), sequedad (Febrer 2001, Amengual 1858-1878).

${ }^{71}$ Enric Valor preferia també el sufix -etat en casos com falsetat, fluixetat i sequetat (Colomina 2010: 179).

72 EscLl i MGad inclouen també falseça. La forma falsea, formada amb el sufix -ea (< -ॉTIA) es documenta en algun autor valencià del primer terç del segle Xx: "Com el llop, quen sa falsea, finchin-se amic dels borregos" (Rafael Gayano Lluch, La última barraca, València, 1926, p. 13), "Hui sols reina la falsea" (Rafael Gayano Lluch, Per saber la veritat, València, 1928, p. 6).

${ }_{73}$ També en els diccionaris mallorquins i menorquins del segle XIX: falsedat (Figuera 1840), falsedad (Amengual 1858-1878; Febrer 2001). 


\subsection{El sufix -il}

L'adjectiu *tartaneril (1837: II, 222), no registrat en els diccionaris, sembla una creació original dels redactors d'El Mole, amb el sufix culte -il, que forma adjectius que indiquen relació a partir de noms, en aquest cas derivat de tartana. Segurament cal dir el mateix de l'adjectiu *ministril 'ministerial' (1855: II, 3), derivat de ministre 'cap de qualsevol dels departaments en què es divideix la governació de l'Estat', sense relació amb el substantiu ministril 'ministrer'.

\subsection{El sufix -im}

El sufix -im forma substantius masculins a partir de noms i de verbs (veg. Duarte i Alsina, 1986: 64, 106; López del Castillo, 2002: 246; Moll, 2006: 253): escurrims (1837: I, 196), rebrotim (1837: I, 316; II, 324), socarrim (1837: I, 128).

\subsection{Els sufix -ina}

Trobem el sufix -ina en la formació de noms a partir de noms i de verbs. En el primer cas tenim +facsiosina (1837: I, 303; II, 246; 1840-41: I, 75, 224; 1855: I, 292), derivat de facció; mot bastant usat en El Mole, per referència, pejorativament, als carlins. No registrat en el DO, en el DGLC, en el DIEC, en el DNV, en el DDLC, ni en el DECat. En el DCVB es recull facciocina 'facció', a partir d'EscLl i MGad. Un poc abans figurava en Escrig (1851).

Són deverbals degollina (1837: II, 321), fuchina (1837: I, 246) i tremolina (1837: I, 260), i probablement probatina (1837: I, 12, 179; II, 285).${ }^{74}$ El substantiu *degollina no es registra en el DCVB, en el DAg, en el DECat, en el DO, en el DGLC, ni en el DIEC, però el recullen el DDLC i el DNV. ${ }^{75}$ A primera vista es podria pensar en un castellanisme, si bé en aquesta llengua sembla ser també un mot de documentació moderna, ${ }^{76}$ i en català és conegut el sufix -ina en la formació de noms deverbals (veg. López del Castillo 2002: 234). ' Tremolina 'gresca, canyaret', amb un sentit similar, es troba en altres textos valencians del segle XIX; en canvi, en el DCVB es recull tremolina 'esgarrifança', sense documentació, i en el DECat (VIII, 742) s'inclou entre els derivats de tremolar, sense més dades. ${ }^{77}$ En castellà, Coromines (DCECH, V, 455) documenta tremolina en el Diccionario de

\footnotetext{
${ }^{74}$ El substantiu pudina (1855: II, 315; 1863: 18, 20, 83; 1870: 100), que el DCVB i el DECat (VI, 851852) recullen en valencià i en tortosí, sense documentació, procediria, segons Coromines (DECat), d'un hipotètic *PŪTǏCǏNUS, -ǏNA. Es registra en el DNV, però no en el DIEC ni en el DDLC.

${ }^{75}$ Es documenta degollina en alguns textos en català de Catalunya i del País Valencià dels segles XIX i XX (CTILC, DDLC).

${ }^{76}$ En el DRAE no es registra degollina fins l'edició de 1884 (NTLLE); en la base de dades CORDE es documenta per primera vegada degollina l'any 1823, en Leandro Fernández de Moratín.

${ }^{77}$ En el DIEC i en el DNV figura tremolina referit a un tipus de cop en el tennis de taula. El DDLC sí que recull tremolina 'brega', que documenta en el periòdic valencià El Tio Nelo (1862).
} 
Autoridades, ${ }^{78} \mathrm{i}$ creu que en aquesta llengua deu procedir de l'aragonés, ${ }^{79}$ o potser d'una forma dialectal catalana o italiana, si bé afirma que "no se emplea hoy en estos idiomas".

+Fuchina (fugina) té relació amb l'aragonés (veg. Martí 2010: 122), ${ }^{80}$ i segurament també *probatina. Aquesta veu no es registra en els diccionaris històrics i normatius catalans, com tampoc en el DRAE ni en el DCECH. ${ }^{81}$ En el NTLLE probatina figura només en el diccionari de Gaspar y Roig (1855), com a veu "provincial". És, en efecte, una veu coneguda a Aragó, Navarra, Àlaba (Borao 1859, Iribarren 1952, Altaba 1985, Andolz 2004, Nagore 1999, Mercadal 2004) i la Manxa (Serna 1980: 198), i arriba als parlars castellanoaragonesos valencians (Llatas 1959: 134).

\subsection{El sufix -isme}

El substantiu *electrisisme: "Allò fon el efecte de l'electrisisme. En manco de un cuart d'hora estaba ya coronada la muralla" (1837: II, 303), que en el text pondera la rapidesa d'una acció. Neologisme no registrat en els diccionaris històrics ni normatius, però que es pot trobar en els diccionaris catalans dels segles XIX i XX anteriors al DGLC (Escrig 1851; MGad; Bulbena 1905, 1919; Fiter 1913; Rovira i Virgili 1919; Vallès 1927), ${ }^{82}$ i és conegut en altres llengües, com en castellà, ${ }^{83}$ en italià ${ }^{84}$ i en francés, encara que poc usat. ${ }^{85}$ Derivat de l'adjectiu elèctric amb el sufix -isme, que forma substantius que designen processos, propietats o sistemes (cfr.

78 En el Diccionario de Autoridades (1739) tremolina 'movimiento ruidoso del aire', 'bulla, confusión de voces y personas que gritan y enredan'. En el CORDE es documenta des de l'Entremés del pelícano y ratón, datat l'any 1691.

79 Igualment, Coromines afirma que tremolar 'temblar' és un aragonesisme en castellà. En els diccionaris aragonesos es troba tremolar, tremolín i altres derivats, però no tremolina. Així, es podria pensar que aquest substantiu s'hagués format en castellà però a partir d'un lexema d'origen aragonés, o català. Sobre els sufixos -ino i -ina en castellà, vegeu Pharies (2002: 333-334, 341-342).

80 També es documenta en la forma fogina (Martí 1997: 359), per relació a fogir, variant de fugir.

${ }^{81}$ Es documenta en una carta en castellà de 1766 de Pedro Andrés Burriel, natural de Buenache (bisbat de Conca).

82 En Bulbena (1905) és definit com 'système qui comprend tous les phénomènes électriques', $\mathrm{i}$ en Vallès (1927) 'conjunt dels fenòmens elèctrics', diferenciat en la definició d'electricitat 'agent natural molt poderós, que es manifesta per atraccions i repulsions, per fenòmens lluminosos, per commocions en l'organisme animal i per efectes químics'.

${ }^{83}$ En castellà no el recull el DRAE, però electricismo sí que apareix en altres diccionaris des del Diccionario nacional (1846-1847) de Domínguez (Moreno Villanueva 2012: 413-414).

${ }^{84}$ Cfr. elettricismo 'elettricità, energia elettrica', com a veu desusada (GDLI, V, 87), documentada en 1746 (GDIU, II, 810).

${ }^{85}$ Apareix en el Dictionnaire critique de la langue française (1787-1788) de Féraud: électricisme "mot nouveau et assez inutile; il a le même sens qu'électricité", i en el Dictionnaire de la langue française (1872-77) de Littré, amb el sentit de 'l'ensemble des phénomènes de l'électricité' (Dictionnaires d'autrefois en ARTFL). 
López del Castillo 2002: 259), i es troba en mots relacionats com magnetisme, galvanisme o electrogalvanisme.

També contenen el sufix -isme els substantius * ${ }^{*}$ santonisme (1855: II, 126) ${ }^{86}$ (cfr. cast. santonismo), *patrisme (1855: I, 319), que podria entendre's com un derivat de pàtria, si no és una reducció de patriotisme, ${ }^{87}$ i *panchisme (1870: 100), forma satírica sorgida per oposició a patriotisme, per relació als polítics oportunistes; igualment, els redactors d'El Mole creen el satític *panchiota (1855: II, 174), per oposició a patriota. ${ }^{88}$

\subsection{El sufix -iste}

Com és habitual en el valencià del segle XIX, el sufix grecollatí -ISTA adopta en masculí la forma flexionada -iste, ${ }^{89}$ exs. carliste (1837: I, 12), caixiste (1837: II, 246), contrabandiste (1837: II, 90), memorialiste (1837: I, 328), periodiste (1837: I, 5), trampiste (1837: II, 275; 1864: 154). Apareix fins i tot en derivats no registrats en els diccionaris històrics i normatius: empleistes (1840-41: I, 213), estanqueristes (1840-41: I, 100), mantafulistes (1837: II, 103), preambulistes (II, 101), trapuliste (1837: II, 252), ${ }^{90}$ prova de la popularitat d'aquest sufix. Els redactors d'El Mole devien considerar el sufix masculí -ista com a castellà, a diferència del valencià -iste, i el fan servir en passatges en aquesta llengua: "Pienso hacerle proponer si quiere pasar ahí, pues es carlista" (1840-41: I, 255). Només en una ocasió llegim -ista en un fragment en valencià, però devia ser per influència del castellà, tenint en compte el context militar on s'ubica: "Y què diria un mestre sabater, contratista de chineles de soldat?" (1837: II, 94).

\subsection{El sufix -itat.}

El sufix -itat forma noms femenins a partir d'adjectius, amb el significat genèric de 'qualitat de', 'condició de' (López del Castillo 2002: 267). Així, els substantius

\footnotetext{
${ }^{86}$ Aquest usat en El Mole juntament amb els adjectius *santonal (1855: I, 359) i * santoner (1855: II, 122), per referència als polítics que en el periòdic són anomenats satíricament santons (cast. santones).

87 Patriòtic i patriotisme són, segons Coromines (DECat, VI, 282), "creacions del francès, on ja es troben des de 1750". En francés patriotisme és derivat de patriote amb el sufix -isme, probablement influït per l'anglés patriotism (Rey 2006).

${ }_{88} \mathrm{Cfr}$. "com s'han donat creus als hòmens notables, per els seus servisis a la pancha...; no, a la pàtria, encara que hui tot és u" (1864: 253).

89 Per a la història d'aquest sufix, veg. Casanova (1984), el qual afirma que -iste triomfa en català occidental des del segle XVI. Popularment també es coneix la forma flexionada de masculí -isto en castellà i en italià (cfr. Pharies 2002: 359).

${ }^{90}$ Mot relacionat amb tràpala, tràpola, trapaler, trapalista, per als quals i altres mots vinculats, veg. el DCVB i el DECat (VIII, 714-715), cfr. trapulante: “-So trapulante (Le quita el almuerzo) / -¡Por vida! / Qu·almorsar més menechat! / -So tunanton!" (Rafael Mª Liern, ¡Carracuca!, València, 1873, p. 20), no registrat en els diccionaris, format amb el mateix sufix que altres mots pejoratius ambante, com hem vist més amunt.
} 
*faliblitat (1870: 104) $\mathrm{i}$ *infaliblitat (1870: 158), no registrats en les fonts consultades, es podrien analitzar com a derivats de l'adjectiu (in)fal-lible amb el sufix -itat, o bé entendre's com a casos de síncope, per dissimilació eliminatòria de la segona, o tercera, segons el cas, "i" d'(in)fal-libilitat per la presència de tres, o quatre, vocals idèntiques en síl-labes consecutives. ${ }^{11}$ La forma ${ }^{*}$ fallibitat (1870: 121) deu relacionar-se amb fallir, i el mateix cal dir d'infallible (1870: 120), com un derivat de fallir amb el sufix -ble, que forma adjectius a partir de verbs.

\subsection{El sufix -itis}

Josep Maria Bonilla fa servir jocosament el sufix culte -itis, usat pròpiament en patologia per indicar afeccions inflamatòries, en el derivat *trampitis: "Si El Mole cau en mans de [...] un especulador trampitis" (1863: 82), on no s'aplica a un lexema culte sinó a un mot popular. López del Castillo (2002: 272) es refereix a altres casos d'ús humorístic d'aquest sufix en adaptacions populars, per relació al tarannà de certes persones.

\subsection{Els sufixos -ment, -menta}

El sufix -menta és relativament productiu en la llengua popular i col·loquial, però, com assenyala López del Castillo (2002: 297-298), els mots formats amb aquest sufix "són pràcticament absents dels diccionaris". Forma noms femenins a partir de verbs, i indica acció i efecte genèric del verb. En El Mole només el trobem en *tornamenta (1837: I, 332), però se'n podrien citar més exemples procedents de textos popularistes valencians dels segles XIX i XX, com abovamenta, acaparamenta, agrunsamenta, apartamenta, brunyimenta, casamenta, disfrassamenta, exaltamenta, glopejamenta, llegimenta, lligamenta, remullamenta, entre altres. D'altra banda, el sufix -ment es troba en alguns substantius no registrats en els diccionaris històrics i normatius: desapareiximent (1840-41: I, 220), fascinament (1855: I, 220).

\subsection{El sufix -ó i casos de doble sufixació}

El sufix -ó s'aplica com a sufix valoratiu a noms: ${ }^{* *}$ canelló (1837: I, 208; II, 136), derivat diminutiu de canella, variant de canyella 'part anterior de la cama sobre la mateixa aresta anterior de la tíbia'. Amb aquest sentit, aplicat a la part anterior de la tíbia, canelló no figura en els diccionaris històrics ni normatius. El DCVB registra a Mallorca canyelló 'la part més prima de la cama d'un animal de ploma'.

El DECat (VI, 574), el DCVB i el DE (715) situen el val. +piuló 'Anas penelope' (1863: 43) entre els derivats de piular. Pel seu caràcter, segurament s’ha

\footnotetext{
${ }^{91}$ Fal·libilitat i infal·libilitat són cultismes procedents, respectivament, del llatí FALLIBILITATE i INFALLIBILITATE.
} 
de relacionar amb el grup de substantius indicadors de l'agent formats amb el sufix -ó (<-ONE) a partir de radicals verbals. ${ }^{92}$

Quant a palpons, present en la locució +a palpons (1840-41: I, 299), se situa entre els derivats de palpar, "amb el sufix -ons" (DE 673), que, segons López del Castillo (2002: 317), forma altres locucions adverbials d'aspecte intensiu, com d'amagatons, a borbollons, etc.

Casos de doble sufixació amb el sufix aspectiu -ó: ell +ó en el substantiu *trompelló, en l'expressió anar a trompellons: "per a esposar-te a que te denunsien, y anar a voltes y trompellons en chent de ploma" (1837: III, 7), referit, en sentit figurat, a les disputes o baralles amb els escriptors. Mot no registrat en el DCVB, el DECat, ${ }^{93}$ el DO, el DGLC, el DIEC ni el DDLC; en el DNV trompelló 'entropessó'. ${ }^{94}$ I iss + ó en el val. ${ }^{\circ}$ calvisó (I, 244), és a dir, calbissó, derivat de calb, com calbot (cfr. DCVB, Martí 2006)..$^{95}$

L'adjectiu xic forma en valencià sovint derivats amb la suma de més d'un sufix diminutiu i afectiu, com tenim en *chiconina (1837: I, 84) ${ }^{96} \mathrm{i}^{\circ}$ chicorrotet (184041: I, 108, 204, 286), aquest darrer tipus, orr + ot + et, ${ }^{97}$ també es troba en el substantiu femení * micorroteta (1840-41: I, 69).

${ }_{92}$ Sobre el sufix -ONE > -ó en català, vegeu Moll (2006: 258-259) i Gulsoy (1993: 332-337). En llatí alguns noms d'animals ja es formaven amb el sufix -O, -ONIS (ex. FALCONE), i en castellà també hi ha designacions d'animals amb aquest sufix (ex. abejón, anadón, etc.) (Pharies 2002: 429-430).

${ }_{93}$ En el DECat (VIII, 864) es registra el valencià trompelló procedent del DAg, però deu ser una errada per trompellot, única forma que es recull en el DAg.

${ }^{94}$ Cfr. a trompellons 'a correcuita': “-Pués tu no eres de Torrelodones? -Sí, però hara m'estic fent valensià a trompellons. Ya sé dir: «Un plat blanc, blau, pla, ple de pebre negre està»" (La Traca, núm. 62, 1886, p. 2), un candidat a diputat per un districte valencià.

${ }_{95}$ Pharies (2002: 432) observa que en castellà el sufix -ón participa com a element final "en un sinnúmero de cadenas sufijales".

96 També es coneix el masculí xiconino: " $t$ 'enrecordaràs qu-avans eren molt chiconinos" (Maximilià Thous, Faust Hernández: La bella Codoñ, Madrid, 1916, p. 8), "Vols que te pegue un pesiguet en la cuixa? [...] Vinga, uno chiconino" (Paco Barchino: Dos pardalets, una aguileta, València, 1922, p. 15), “Des de chicotet; vaig nàixer aixina; aixina, no, més chiconino, un pamet y mig" (Alfred Sendín, Tonica la del llunar, València, 1926, p. 5), i xiconín: “Com en la botiga venen de tot, l'agafat pal chiconín" (Joan Alegre: La boda de l'hostaler, València, 1917, p. 18). Mots no registrats en els diccionaris històrics ni normatius.

${ }^{97} \mathrm{Cfr}$. altres derivats de $x i c$ amb el sufix orr combinat amb altres sufixos diminutius que trobem en textos valencians dels segles XIX i XX: xicorrotiu, -iua: "És algo chicorrotiu, / que brilla, que se somriu" (Ramon Andrés Cabrelles, en Foc y Flama, núm. 8, 1913, p. 8), la quintilla, "Poeta vach ferme, / cantan-li a la señor-ama / cuant era chicorrotiua" (Estanislau Alberola: Poesies, València, s. a., p. 11), xicorringo: "gran com un mosquit, o xicorringo, xicorringo com un bou?" (Joan M. Borràs Jarque: El dir de la gent, Biblioteca de Catalunya, ms. 5359, 1935, p. 49), xicorronino: "un pehuet chicorronino" (P. Peycé, en Constantí Llombart: Tipos d'auca, València, 1878, p. 126), amb la mateixa terminació que xiconino; en aragonés es coneix chicorrón 'pequeño; muy pequeño' (Nagore 1999, Andolz 2004), també amb el sufix orr. 


\subsection{El sufix -òria}

El substantiu * sinfonòria no figura en els diccionaris. Apareix en el context de la representació frustrada de l'òpera Roberto Desvereux, substituïda per "la òpera del tio Escaramusa", la qual cosa provocà la protesta del públic: "Entonses rebenta la bufa dels espectadors que anaba unflan-se des de la sinfonòria, y esclafa tot lo públic cridant: "Fora!, fora!, fora!", y pegaben en les taules en los bastons, y cridaben y chiulaben" (1840-41: I, 301); sembla una variant de simfonia, amb el mateix sufix que es troba en cridòria. ${ }^{98}$

\subsection{El sufix -ós, -osa}

El sufix -ós, -osa és adjectivador de substantius: *caramelós (1855: II, 107), *caramelosa (1837: II, 96), riallós (1837: II, 263), riallosa (1837: I, 12; III, 69), +tarquimós (1840-41: I, 131), registrat en el DNV i en el DDLC, però no en el DIEC, *tenalloses: "les mandíbules tenalloses" (1840-41: I, 151).

\subsection{El sufix -ú, -una}

El sufix -ú, -una forma adjectius a partir de bases nominals, amb el valor de 'relatiu a' (veg. López del Castillo 2002: 381). En El Mole el trobem en *facsiosuna: "llibertat facsiosuna", "artilleria facsiosuna" (1840-41: I, 190, 191), derivat de facciós (en el text, referit als carlins), i en *fraruna: "república fraruna", "rasa fraruna" (1840-41: I, 53; II, 3), així com en el castellanisme *cangrejuna: "chent cangrejuna" (1840-41: I, 279), en tots aquests mots amb caràcter pejoratiu.

\subsection{Els sufixos -ungo, -unga, -ingo, -inga}

El substantiu *trampantunga 'trampa, engany, frau' (1864: 233, 235, 284; 1865: 379; 1870: 170), 'trampós, bergant, oportunista' (1865: 436), derivat aspectiu de trampa, amb un sufix despectiu poc corrent en català, és un mot no registrat en les fonts consultades, que sembla una creació dels redactors d'El Mole. La mateixa terminació es troba en aquest periòdic en l'antropònim burlesc Pitunga, per referència al ministre Pío Pita: “El Mole ix com la llangosta de les pandilles, com ixqué cuant a la pandilla de Mendisàbal, y cuant a la pandilla de Pita Pitunga Pitanga" (1840-41: I, 211), i en el substantiu +sandunga (1864: 278), de possible origen caló documentat en valencià des de principis del segle XIX (Martí 2006). ${ }^{99}$

\footnotetext{
${ }^{98}$ Duarte i Alsina (1986: 110), a propòsit del sufix -òria i de cridòria, consideren la possibilitat, no documentada, "de formacions del tipus: xerròria o xisclòria".

${ }^{99}$ Segons el DCECH $(\mathrm{V}, 150)$, sandunga és una veu "de origen incierto, quizá gitano", encara que hi exposa també altres alternatives. Més convençut de l'origen caló d'aquest mot es mostra Ropero Núñez (2007: 63), per a qui "es muy probablemente un préstamo del caló", i addueix a favor d'aquesta opinió el fet que aparega recollit en els diccionaris gitanos. En català sandunga es considera generalment un castellanisme (DCVB; DECat, VII, 652), si bé cal tenir en compte que
} 
En altres textos valencians del segle XIX es documenta, amb una terminació idèntica, també amb caràcter pejoratiu, el substantiu mamandungo, - $a$ 'persona aprofitada, oportunista'100 i femení mamandunga 'interés propi, conveniència particular', derivats de mamar fig. 'obtenir o gaudir un profit, un benefici' (Martí 2006), ${ }^{101}$ i el DCVB registra a Beniopa mamandunga 'munyequeta abeurada de llet amb sucre, que es dóna als infants molt mamadors perquè s'entretinguin'. Es tracta de la mateixa terminació de *sangandungo (1837: II, 123, 1855: I, 303), procedent del castellà zangandungo, zangandongo 'hombre inútil y perezoso', segons Coromines (DCECH, VI, 72), derivat de zángano. ${ }^{102}$ Per tant, possiblement mots com sandunga i sangandungo degueren afavorir la popularitat del sufix ungo, -unga en valencià, que hi seria aprofitat com a sufix valoratiu en la formació de veus d'àmbit col-loquial, com trampantunga. En relació amb tot això, com veurem tot seguit, documentem també en els textos valencians les terminacions -ingo, - $a$ i -ango, - $a$, que cal posar en relació amb-ungo, $-a$, i amb els sufixos afectius i pejoratius castellans -ango / -anga, -engo / -enga, -ingo / -inga, -ongo / -onga, -ungo / -unga (veg. Lang 1990: 162-163, Pharies 1990, 2002), així com amb la presència en català d'alguns mots en -ang-, -eng-, -ing-.

Respecte a trampantunga, cal relacionar-lo amb el sinònim *trampantulla 'engany, trampa, frau' (1856: 48), que, encara que menys freqüent, es documenta també en El Mole, en aquest cas amb la terminació -ulla. Com trampantunga, és una veu no registrada en els altres textos consultats. Coromines (DECat, VIII, 715) creu probable que el tortosí trapantoll 'cansament per excés de moviment, etc.' siga una "adaptació del cast. trampantojo (< trampa ante ojo), si bé adaptat a la forma i sotmès al sentit del cat. atrapar". En aquest sentit, es podria considerar també el nostre trampantulla una possible adaptació del cast. trampantojo, ${ }^{103}$ documentat des del segle XVI (DCECH, V, 592-593; CORDE), o millor del femení

s'hi documenta fins i tot abans que en castellà. En efecte, en el DCECH el cast. sandunga es documenta per primera vegada en 1849; en el CDE es documenta l'any 1828 en el Duque de Rivas, i en el CORDE en les poesies de José Somoza (1811-1842). En català trobem sandunga ja en un col-loqui que forma part d'una còpia d'una recopilació de 1803 de col-loquis anteriors, del segle XVIII, i en un altre col-loqui de 1820 (veg. Martí 2006).

${ }^{100}$ Aplicat sovint en política al profit interessat, obtingut sense mèrits.

101 Es coneix també en el castellà de la Canal de Navarrés: mamandungo 'el que quiere aprovecharse sin escrúpulos de una situación para obtener un beneficio' (Ponce Palop 2014: 100). Amb un sentit diferent, en andalús mamandungo 'tejeringo, churro' (Pharies 2002: 527). Cfr. cast. mamar i mamancia.

102 L'evolució, segons el DCECH, seria *zanganongo > *zangadongo > zangandongo, amb propagació de la nasal. En aquest diccionari es documenta zangandongo al segle XVIII, des del Diccionario de Autoridades (1734), i zangandungo en Bretón de los Herreros. Pharies (2002: 527) afirma que el sufix -ungo es testimonia per primera vegada en castellà en zangandungo (zangandongo). En val. documentem sangandongo per primera vegada en un col-loqui de 1813: “yo em torne loco / sempre que em pose a pensar / el número de sangandongos / que varen dechenerar / de aquella hombria de bé" (Rahonament y coloqui nou de Chusep el Bo y Providènsia, p. 2), per relació als afrancesats, i sangandungo també des de la primera meitat del segle XIX, més usual.

${ }^{103}$ Sobre les adaptacions del fonema castellà / $\mathrm{x} /$ en $/ \lambda /$, vegeu Veny (2006: 77-90). 
trampantoja, ${ }^{104}$ influït potser en la terminació per altres mots catalans amb -ulla, com ramulla, agulla, etc. ${ }^{105}$

Josep Maria Bonilla fa servir la terminació pejorativa -ingo en un altre derivat jocós de trampa, l'adjectiu *trampantingo $(1863$ : 84, 85, 86), que apareix en El Mole juntament amb tres mots més de caràcter pejoratiu que comparteixen la mateixa terminació: *gafantingo (1863: 84), * gafautingo (1863: 85, 86), derivats respectivament de gafar (o agafar) i gafaüt, ${ }^{106} \mathrm{i}$ * radicatingo (1863: 84, 86), que cal relacionar amb l'adjectiu radical. Aquestes tres denominacions apareixen en un text satíric sobre la història primitiva d'Espanya, on són els noms dels "partits" que aleshores suposadament es barallaven per la supremacia, com una metàfora jocosa i imaginativa de les disputes dels partits polítics contemporanis, envers els quals Bonilla era molt crític. Pharies (2002: 338-340) es refereix a la gènesi del sufix -ingo en castellà, deguda a la variació vocàlica amb el nucli consonàntic sufixal -ng-, i afegeix que en no pocs casos la variació vocàlica de la sèrie en -ngs'aplica a una mateixa base lèxica, com l'andalús mamandungo 'tejeringo' / mamindangos 'dulces de Navidad' (2002: 528); seria també, doncs, el cas de trampantunga / trampantingo. Aquesta variació es dona així mateix, com hem vist, en el cognom burlesc Pita Pitunga Pitanga. ${ }^{107}$

López del Castillo (2002: 250) dona compte de l'infix intensiu -ing-, amb el qual, segons aquest autor, només es coneix "la sèrie formada damunt "pell»", com pelleringa, pellingo, etc. Bruguera (2001: 338) es refereix a -anga, "sufix dubtós i no explicat que es dóna en mitja dotzena de mots", i, "per analogia, si més no per la presència de -ng-, hi podríem afegir uns quants altres [mots] en -enga [...], i uns altres en -inga, la majoria d'origen francès". Pharies (1990: 81-86) cita diversos mots catalans formats amb els sufixos $-n c^{-} /-n g-$, la majoria amb -enc, però també amb altres terminacions: -anc (burxanc, escorranc, foranc, pollanc), -anca (calanca, fallanca, flixanca, llosanca), -anco (favanco, potranco), -ango (brutango, fandango), -anga (bullanga, pellanga, xaranga), -engo (badalengo, guadengo), -enga (mallerenga, merenga), -enco (magenco), -inga (berlinga, carlinga, futinga, potinga, pudinga, ralinga, siringa, xeringa), -ingo (bladingo, pelleringo), -onc (floronc), -onga (candonga). Cal dir que entre aquests mots es troben alguns castellanismes i gal-licismes. En valencià també es coneixen alguns diminutius intensius amb -ingo, com menudingo (DCVB), xicorringo (Borràs Jarque, El dir..., p. 49), xicotingo (Josep Pascual Tirado,

\footnotetext{
104 Es documenta en Samaniego, l'any 1797 (CORDE).

105 Sense oblidar que en castellà, tot i que no sembla haver-hi documentació antiga, no és desconeguda la variant trampantuja, amb $u$ : "incita a la trampantuja, a la mentira" (http://elcaballeroespanol.blogspot.com.es/2010/12/verano.html).

106 Sobre gafaüt, mot que va popularitzar Bernat i Baldoví, veg. Martí (2011).

${ }^{107}$ Hem vist més amunt també la terminació -anga en morrondanga; altres mots que documentem en valencià als segles XIX i XX amb aquesta terminació són bullanga, mandanga, moixiganga, pelandanga (Jesús Morante, iLleve's eixos pantalons!, València, 1932, p. 32), poliganga (Conversasió que tingueren Saro Perrengue, carreter de Godella, y el dotor don Bonifacio Cudol, abogat de Valènsia, en lo mes de agost de l'añy 1813, València, p. 4), i -ango, ex. arromango, burrango, dingolandrango, dingondango, fandango, sanguango, mandango, mandrango, etc.
} 
De la meua garbera, Castelló, 1935, p. 236), i s'hi documenten alguns castellanismes amb aquesta terminació, com pingo, mandingo, ${ }^{108}$ així com l'hipocorístic Mingo, ${ }^{109}$ de Domingo, encara que en aquests darrers mots la terminació -ingo té un altre origen.

\subsection{El sufix -ús}

Duarte i Alsina (1986: 71) comenten que el sufix aspectiu -ús (del llatí -UCEU) “té un clar matís despectiu [...] i una minsa vitalitat". Bruguera (2001: 367) i López del Castillo (2002: 385) registren també el sufix -ús, -ussa amb valor pejoratiu en substantius i adjectius. ${ }^{110}$ En El Mole apareix -ús en +malaltús (1837: I, 35) i pobrús (1840-41: I, 194), que tenen també un caràcter despectiu o pejoratiu.

\subsection{El sufix $-u t,-u d a$}

Per últim, a partir de l'adjectiu brau, els redactors d'El Mole formen el derivat intensiu * brabut (per bravut) (1855: II, 13), aplicat a un toro brau. Igualment, amb el mateix sufix intensiu -ut, a partir del castellanisme, o aragonesisme, agüela deriven l'adjectiu *agüeluda: "se posaba una vella molt agüeluda tots los dies a la porta de palàsio" (1840-41: II, 143), probablement per expressar que era una vella decrèpita; cfr. agüelot 'demasiado abuelo o viejo' (MGad).

\section{CONCLUSIONS}

Els redactors d'El Mole es van valdre, entre altres recursos, de la derivació en la seua tasca d'elaborar un registre periodístic en català, que resultés atractiu per al públic ampli al qual anava destinada la publicació, i que al mateix temps cobrís les necessitats del gènere periodístic. L'estudi permet provar la capacitat del valencià del segle XIX per a la creació lèxica utilitzant els mecanismes interns. Així mateix, s'han estudiat els mots de major interés formats per sufixació. Hem trobat diversos mots formats per aquest procediment no enregistrats en les altres fonts escrites catalanes consultades, almenys en les prèvies o contemporànies, sense correspondències directes en castellà, i que deuen ser creacions dels redactors d'El Mole. En aquest sentit, es nota que alguns sufixos es mostren més productius en la creativitat lèxica en el periòdic: -ar (clossar, genibrar), -al (pessetal, carabassinal, cegal, boual, diarral, graciosal, monyicotal, desgovernal), -ante (pillante, remendante), -

\footnotetext{
${ }^{108}$ En castellà mandingo, mandinga "própiamente nombre étnico de los negros de una gran región del Norte de Guinea" (DCECH, III, 801), documentat ja a principis del segle XVI (CORDE); en català trobem mandingo al segle XVII en el valencià Pere Jacint Morlà, com a adjectiu, sinònim de ‘negre' (Ferrando 1995: 117; Mas i Usó 1998: 211).

${ }^{109}$ Cfr. "-Oy, Mingo, tu per así? / -Vacha un bon dia y salut" (Josep Garcia Capilla: Un adrés del baratillo, València, 1873, p. 7).

${ }^{110}$ Colomina (1991: 53), per la seua part, registra un sufix -ús diminutiu.
} 
dura (-ura) (contadura, desgovernadura, posadura, soterradura), -ero (molero, papafiguero, xarlatanero, polvillero, ambicionero, mamero, lliberalero, jefero), -il (tartaneril, ministril), -isme (patrisme, panxisme), -ingo (trampantingo, gafautingo i gafantingo, radicatingo), -ut, -uda (bravut, agüeluda). Unes altres formes derivades per sufixació que només registrem en El Mole i que probablement en són creacions pròpies són: desgovernador, burrència, molada, ateniensos, trampitis, sinfonòria, tornamenta, cegueria, tenallós.

A banda d'aquests mots, s'ha estudiat el procés de sufixació en El Mole, i s'han trobat mots no enregistrats en els diccionaris històrics i normatius, no documentats, així com primeres documentacions. Hem constatat també la variació formal en els sufixos -ada (-àa,-à) i -ador (-aor), la presència conjunta de les variants -ar i -al en valencià, la preferència d'El Mole i dels textos valencians de l'època pel sufix -etat sobre -edat. Igualment, hem estudiat la convivència de les variants sufixals -er i -ero en el valencià del segle XIX, i la vitalitat que mantenia encara la forma genuïna -er en la formació de paraules noves i en l'adaptació de noms d'origen castellà amb -ero. També s'observa la convivència de -er i -ero en alguns mots. El sufix -ero es troba sobretot en veus que en castellà coneixen una forma similar amb aquest sufix. No és tan habitual trobar -ero en mots que en castellà mostren solucions diferents.

S'observa, així mateix, que algunes veus estan formades amb sufixos diferents als que han acabant imponent-se en la llengua literària moderna, per ex. donada 'donació', contratança, adormidera, soterradura, ribereny, centener 'centenari', cocero, femera, ministral 'ministerial', degollina, provatina, electricisme, desapareiximent, fascinament, entre altres.

Des del punt de vista de la lexicografia normativa, constatem que alguns mots formats per derivació ben coneguts en valencià no han estat inclosos en el DIEC, si bé figuren en el DNV. És el cas de veus com samugada, baquinada, empastrada, carxotada, pardalam, xaramiter, falsetat, fluixetat, sequetat, pudina, degollina, trompelló, calbissó, tarquimós.

En la creació lèxica per sufixació en alguns casos està present la interferència lingüística, però aquesta provoca, de vegades, solucions creatives i originals. Així, hi ha, com hem vist, alguns sufixos introduits amb mots procedents del castellà que han estat aprofitats per a formar mots nous en català, com els sufixos -ante, -ero o -unga. En algunes ocasions tant el lexema com el sufix són d'origen foraster, però el derivat, no documentat en castellà, sembla una formació pròpia (polvillero, millonero, jefero, pillante, remendante). Igualment, es documenten alguns lexemes castellans amb sufixos catalans, com condet, sombreret, reposter, prisioner. El paper destacat de l'aragonés sobre el valencià es pot observar també en alguns derivats presents en el periòdic, com femera, fugina o probatina.

En total, s'han analitzat trenta-quatre sufixos diferents, a més d'alguns casos de sufixació múltiple, i alguns sufixos que presenten variants. En aquest darrer cas, estudiem la relació entre les variants, que poden estar determinades per l'origen culte o hereditari del sufix (-etat / -edat), per la variació vocàlica en un 
mateix nucli consonàntic sufixal (-ng-), per la interferència lingüística (-er / -ero), o per l'analogia, que determina la formació del masculí -iste.

\section{BIBLIOGRAFIA}

Altaba EsCORIHUElA, J. (1985), Teruel. Peculiaridades de nuestro léxico popular, Saragossa, Librería General.

Amengual, J. J. (1858-1878), Nuevo diccionario mallorquín-castellano-latín, 2 vols. Palma, Juan Colomar.

ANDOLZ, R. (2004), Diccionario aragonés, Saragossa, Mira.

[ARTFL] The ARTFL Project [en línia]. Chicago, University of Chicago [Consultes: 2017]. Disponible a: <http://artfl-project.uchicago.edu/content/dictionnaires-dautrefois $>$.

BALAGUER, E. (1988), “Una revista popular valenciana: El Mòle (1837 i 1840-41)”, Caplletra, 4, 69-78.

BORAO, J. (1859), Diccionario de voces aragonesas, Saragossa, Calisto Ariño.

BRUGUERA, J. (2001), "Sufixos fòssils del català", en Estudis de Llengua i Literatura catalanes XLII. Miscel-lània Giuseppe Tavani, vol. 1, Barcelona, PAM, 333-372.

BulBenA, A. (1905), Diccionari català-francés-castellà, Barcelona, Francesch Badia.

BulbeNA, A. (1919), Diccionario catalán-castellano, Barcelona, imp. de Vda. Badía Cantenys.

CABRÉ, Mำ T. (1994), A l'entorn de la paraula (II). Lexicologia catalana, València, Universitat de València.

CABRÉ, Ma T. (2008), “La derivació”, en Gramàtica del català contemporani, Solà, J. (dir.), vol. 1, Barcelona, Empúries, 731-774.

CASANOvA, E. (1984), "Sobre la moció del sufix -ISTE / -ISTA", Boletín de la Sociedad Castellonense de Cultura, 60, 259-265.

CASANOVA, E. (1995), “Els hipocorístics en -o [tipus Manuel > Nelo] en valencià: una interpretació", Societat d'Onomàstica. Butlletí interior, 62, 28-36.

[CDE] DAVIES, M. (2008). Corpus del español [en línia] [Consultes: 2017]. Disponible a: $<$ https://www.corpusdelespanol.org/hist-gen/2008/>.

CODONYER BALLESTEROS, R. A. (2000), Un segle de publicacions periòdiques en valencià: catàleg, València (1827-1936), tesi doctoral dirigida pels Drs. Emili Casanova i Antoni Laguna, València, Universitat de València.

ColOMinA, J. (1991), El valencià de la Marina Baixa, València, Generalitat Valenciana.

COLOMinA, J. (1995), Els valencians i la llengua normativa, Alacant, Institut de Cultura "Juan Gil-Albert".

Colomina, J. (2010), “Enric Valor i el lèxic normatiu”, en Enric Valor. El valor de les paraules, València, AVL, 152-167.

COLOMINA, J. (2017), El sufix-al/-ar amb valor col-lectiu, abundancial i augmentatiu. Un estudi de morfofonologia lèxica iberoccitanoromànica, Alacant, Universitat d'Alacant.

[CORDE] ReAl ACADEMIA ESPAÑOlA. Banco de datos (CORDE). Corpus diacrónico del español [en línia] [Consultes: 2017]. Disponible a: <http://www.rae.es $>$.

[CTILC] INSTITUT D’ESTUDIS CATALANS. Corpus Textual Informatitzat de la Llengua Catalana [en línia], Barcelona [Consultes: 2017]. Disponible a: <http://ctilc.iec.cat/>. [DAg] Diccionari Aguiló (1915-1934), 8 toms, Barcelona, IEC. 
[DCCLFI] Diccionari català-castellà-llatí-francés-italià. Per una societat de Catalans (1839), Barcelona, Joseph Torner.

[DCECH] COROMINES, J., con la colaboración de j. a. pascual (1980-1991), Diccionario crítico etimológico castellano e hispánico, 6 vols., Madrid, Gredos.

[DCVB] Alcover, A. M. i MOLL, F. DE B. (1988), Diccionari Català-Valencià-Balear, 10 vols., Palma de Mallorca, Moll.

[DDLC] Institut d'Estudis Catalans. Diccionari descriptiu de la llengua catalana [en línia]. Barcelona [Consultes: 2017]. Disponible a: $<$ http://dcc.iec.cat/ddlc/scripts/indexA.asp>.

[DE] BRUGUERA, J. (2006), Diccionari etimològic, Barcelona, Enciclopèdia Catalana.

[DECat] COROMINES, J. (1988-1991), Diccionari etimològic $i$ complementari de la llengua catalana, 10 vols., Barcelona, Curial.

[DGLC] FABRA, P. (1932), Diccionari general de la llengua catalana, Barcelona, Llibreria Catalònia.

[DIEC] INSTITUT D’ESTUDIS CATALANS (1995), Diccionari de la llengua catalana, Barcelona.

[DNV] ACADÈMIA VALENCIANA DE LA LLENGUA. Diccionari normatiu valencià [en línia]. València [Consultes: 2017]. Disponible a: <http://www.avl.gva.es/dnv>.

[DO] FABRA, P. (1917), Diccionari ortogràfic, Barcelona, IEC.

DUARTE, C. i AlSINA, À. (1986), Gramàtica històrica catalana, vol. 3, Barcelona, Curial. El Mole, València, 1837-1870.

ESCARTí, V. J. (ed.) (1999), Joaquim Aierdi, Dietari, Barcelona, Barcino.

[EscLl] EsCRIG, J. i LlOMBART, C. (1887), Diccionario valenciano-castellano, València, Pascual Aguilar.

ESCRIG, J. (1851), Diccionario valenciano-castellano, València, J. Ferrer de Orga.

EsteVe, J., Belvitges, J. i JuglÀ, A. (1803-1805), Diccionario catalán-castellano-latino, Barcelona, Tecla Pla.

FEBRER I CARDONA, A. (2001), Diccionari menorquí, español, francès i llatí, edició crítica i estudi introductori a cura de Paredes, m., Barcelona, IEC.

FERRANDO, A. (ed.) (1995), Pere Jacint Morlà. Poesies i col-loquis, València, IVEI.

FigUeRA, P. A. (1840), Diccinari mallorquí-castellà, Palma, Esteva Trias.

FITER, J. (1913), Enciclopèdia moderna catalana, 5 vols., Barcelona, Joseph Gallach.

[GDIU] Di MAURO, T. (2000), Grandi dizionario italiano dell'uso, Torino, Unione Tip. Editrice Torinese.

[GDLI] BATTAGLIA, S. (1961-2002), Grande dizionario della lingua italiana, 21 vols., Torino, UTET.

GÓMEZ-FERRER LOZANO, M. (2002), Vocabulario de arquitectura valenciana: Siglos XV al XVII, València, Ajuntament de València.

INSTITUT D'ESTUDIS CATALANS (2016), Gramàtica de la llengua catalana, Barcelona.

GUILLAMET, J. i MAURI, M. (eds.) (2015), Catàleg històric general de la premsa en català. Volum 1. L'eclosió de periòdics, 1641-1898, Barcelona, IEC.

GULSOY, J. (1993), Estudis de gramàtica històrica, València / Barcelona, IUFV / PAM.

IRIBARREN, J. M. (1952), Vocabulario navarro, Pamplona, ed. Gómez.

LABÈRNIA, P. (1839-40), Diccionari de la llengua catalana ab la correspondència castellana y llatina, Barcelona, Espasa Germans.

LANG, M. F. (1992), Formación de palabras en español, Madrid, Cátedra.

LAPESA, R. (1984), Historia de la lengua española, Madrid, Gredos. 
LlATAS, V. (1959), El habla del Villar del Arzobispo y su comarca, 2 vols., València, Institución Alfonso el Magnánimo.

Llorente FalCó, T. (2001), Memorias de un setentón, 3 vols., Valencia, Federico Doménech.

LÓPEZ DEL CASTILlO, LL. (2002), Diccionari de formació de paraules, Barcelona, ed. 62.

MARTÍ, J. (2006), Diccionari històric del valencià col-loquial (segles XVII, XVIII i XIX), València, Universitat de València.

MARTí, J. (2010), “La presència del català i de l'aragonès a principis del segle XX en els parlars valencians de base castellanoaragonesa. L'obra filològica de Torres Fornes (1903)", Llengua \& Literatura, 21, 87-133.

MARTí, J. (2011), Diccionari de Josep Bernat i Baldoví (1809-1864) en el seu context històric, València, Denes.

MARTí, J. (2012), “Afinidades léxicas aragonesas en el valenciano del siglo XIX”, Archivo de Filología Aragonesa, 68, 143-176.

MARTí, J. (2013), "Poemes burlescos, satírics, laudatoris i de disbarats en un manuscrit valencià del segle XVIII", eHumanista/IVITRA, 3, 230-257.

MARTÍ, J. (2015), “El lèxic popular valencià en la literatura de les primeres dècades del segle XX: l'aportació de Faust Hernández Casajuana”, Caplletra, 59, 75-97.

MARTINES, J. (2000), El valencià del segle XIX, València / Barcelona, IIFV / PAM.

MARTíNEZ GALLEGO, F.-A. (2015), “Una premsa nombrosa i efímera al País Valencià”, en Catàleg històric general de la premsa en català. Volum 1. L'eclosió de periòdics, 1641-1898, Guillamet, J. i Mauri, M. (eds.), Barcelona, IEC, 187-197.

MAS I Usó, P. (1998), Poesia acadèmica valenciana del Barroc, Kassel, Edition Reichenberger.

Mercadal, M. (2004), Vocabulario de la Sexma de la Honor de Huesa del Común (Teruel), Saragossa, Institución "Fernando el Católico".

[MGad] MARTí I GADEA, J. (1891), Diccionario valenciano-castellano, València, José Canales Romà.

MOLL, F. DE. B. (2006), Gramàtica històrica catalana, València, PUV.

MomblanCH i GONZÁLBEZ, F. DE P. (2003 [1960]), Historia de la Albufera de Valencia, València, Ajuntament de València.

MORELl I MONTADI, C. (1986), La famosa comèdia de la Gala està en son punt. Estudi i edició, Barcelona, Curial / PAM.

Moreno VillanueVA, J. A. (2012), "La inclusión del léxico de la electricidad en los diccionarios de mediados del siglo XIX", en Avances de Lexicografía Hispánica (I), Nomdedeu, A., Forgas, E. i Bargalló, M. (eds.), Tarragona, URV, 411-426.

NAGORE, F. (dir.) (1999), Endize de bocables de l'aragonés, Osca, Instituto de Estudios Altoaragoneses.

[NTLLE] REAL ACADEMIA ESPAÑOLA. Nuevo tesoro lexicográfico de la lengua española [en línia]. [Consultes: 2017]. Disponible a: <http://www.rae.es>.

Orellana, M. A. D' (1795), Catàlogo dels pardals de l'Albufera de València, València.

PARDO, L. (1942), La Albufera de Valencia, Madrid, CSIC.

PHARIES, D. (1990), The Origin and Development of the Ibero-Romance -nc- / -ng- Suffixes, Tübingen, Max Niemeyer Verlag.

PHARIES, D. (2002), Diccionario etimológico de los sufijos españoles, Madrid, Gredos.

PONCE PALOP, J. L. (2014), Ensayo sobre la filología chellina. El habla de Chella [en línia]. [Consultes: 2017]. Disponible a: <www.fayos.org $>$.

REY, A. (dir.) (2006), Dictionnaire historique de la langue française, París, Le Robert. 
ROPERO NÚÑEZ, M. (2007), “Tratamiento lexicográfico y sociolingüístico de los gitanismos del español en el DRAE (desde la Primera edición de 1780 hasta la Vigésima segunda de 2001)", en Sociolingüística andaluza 15. Estudios dedicados al profesor Miguel Ropero, Carbonero Cano, P. (dir.), Sevilla, Universidad de Sevilla, 13-80.

Rosselló I VerGer, V. M. (1995), L'Albufera de València, Barcelona, PAM.

ROVIRA I VIRGILI, A. (1919), Diccionari català-castellà E castellà-català, Barcelona, Antoni López.

RULL, X. (2004), La formació de mots, Vic, Eumo.

SAURA, J. À. (1878), Novíssim diccionari manual de las llenguas catalana-castellana, Barcelona, llibreria d'Esteve Pujal, editor.

SECO, M. (1970), Arniches y el habla de Madrid, Madrid / Barcelona, Alfaguara.

SERNA, J. S. (1980), “Como habla la Mancha (Diccionario manchego). Suplemento (inédito)", Al-Basit, 8, 185-202.

SIMBOR, V. (1989), “La Renaixença al País Valencià”, Caplletra, 4, 9-41.

VALLÈs, E. (1927), Pal-las. Diccionari català-castellà-francés, Barcelona, Horta S. A.

VENY, J. (2003), Escriptura i oralitat a Mallorca, Mallorca, Moll.

VENY, J. (2006), Contacte i contrast de llengües i dialectes, València, PUV.

VIDAL, I. (1995 [1851]), Catálogo de las aves de la Albufera. Reproducción de las ediciones de 1851 y 1856 con comentarios a las mismas y listado actualizado de las aves de la Albufera de Valencia realizado por Rafael Pardo, València, París-Valencia.

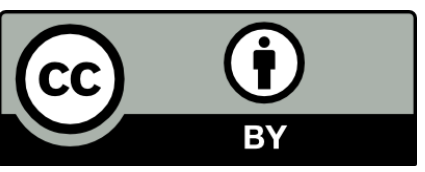

Llevat que s'hi indiqui el contrari, els continguts d'aquesta revista estan subjectes a la llicència de Creative Commons: Reconeixement 3.0 Espanya. 